(Presented at the Tilburg conference on "The Derivational Residue in Phonology", October 1995. To appear in B. Hermans \& M. van Oostendorp, eds., The Derivational Residue in Phonology)

\title{
Surface opacity of metrical structure in Optimality Theory
}

\section{Introduction ${ }^{1}$}

\author{
René Kager \\ University of Utrecht
}

A central hypothesis of rule-based generative phonology is that rules have exclusive access to representations that occur in the stage of the derivation at which they apply. Whether or not a rule's conditioning environment is satisfied in the surface form is totally irrelevant to its actual application. Or to put it differently, derivational phonology is 'output-blind'. Of course it may well occur that some rule is ordered so late that no other rule will destroy its context in the output. But such surface transparency is accidental only (a mere side-effect of rule-ordering), and not principled. Analogously, derivational phonology is 'input-blind' as well, since for a rule's application it is irrelevant whether or not its structural description had been satisfied as early as in the underlying representation. In sum, rules have access to lexical representations only indirectly, and (in principle at least) cannot distinguish derived from non-derived properties ${ }^{2}$.

A derivational theory with extrinsic rule ordering easily expresses generalisations that are not surface-true, and it specifically predicts opaque surface forms. I will use the notion 'opacity' as referring to situations in which a disparity exists between a surface form and the context of application of a phonological process. Two types of opacity are known from the literature (see Kenstowicz \& Kisseberth 1979, and references cited there). First, a form may display the effects of some phonological rule, but fail to meet its context of application at the surface. This situation arises when, at some point in its derivation, a form matches a rule's structural description (hence undergoes the structural change), after which some subsequent rule destroys the former rule's context of application. The effect is an 'over-application' of the rule with respect to its output phonological shape. This kind of interaction is illustrated by an example from Turkish (Kenstowicz \& Kisseberth 1979:192). First a minor rule deletes the initial consonant of the possessive suffix /-si/ after consonant-final stems. The triggering consonant is subsequently deleted by a second minor rule of intervocalic $k$-Deletion ${ }^{3}$ :

$\begin{array}{ll}\text { /ayak-sI/ } & \text { 'his foot' } \\ \text { ayak-I } & \text { Consonant deletion in /-sI/ } \\ \text { aya-I } & \text { k-Deletion } \\ \text { [aya-I] } & \end{array}$

The second class of cases has precisely the opposite characteristics: a surface form meets the structural description of a rule, but it fails to show its effects. This situation arises when the form fails to meet a rule's structural description at its proper point of application in the derivation,

\footnotetext{
1 This paper has benefitted from discussions with John Alderete, Laura Benua, Jan Don, Bruce Hayes, Ben Hermans, John McCarthy, and Wim Zonneveld. Full responsibility for any mistakes is mine, of course. The research for this paper was sponsored by the Royal Netherlands Academy of Sciences (KNAW).

${ }^{2}$ Constraining rules such that they apply only to 'derived forms' (e.g. strict cyclicity) can be seen as breaking away from derivationalism in a strict sense.

${ }^{3}$ Zimmer (1975) states the rule as deleting the final $k$ of a polysyllabic stem when it is intervocalic.
} 
and comes to match it only later, due to subsequent rules (a situation of 'counter-feeding'). The effect is an 'under-application' of the rule to a form, in terms of its output phonology. Consider the following example from French (Schane 1968). Schane's rule of Nasalisation (nasalising vowels before nasal consonants in syllable 'Coda' position) underapplies to $/ \mathrm{s} /$ since at the point in the derivation where Nasalisation applies this vowel fails to match the rule's context. It only comes to match this context after a subsequent rule of Schwa deletion:

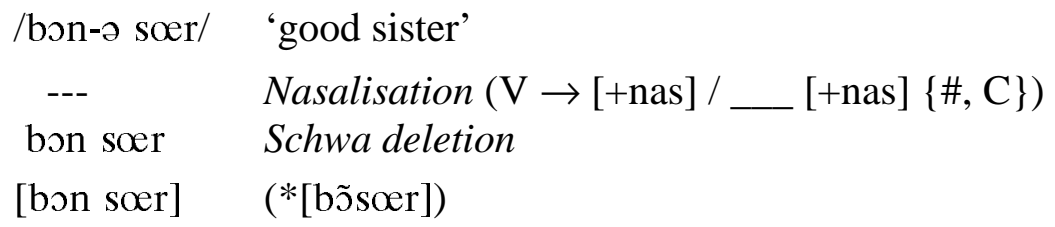

It has been pointed out by Hooper (1976) and many others that this 'abstract' analysis only serves to maintain the otherwise unsupported assumption that nasalisation is not distinctive in vowels in French. These criticists argue that Schane's rule-ordering analysis may capture the historical developments, rather than the synchronic situation, in which nasalisation has become distinctive in vowels - due to opacity.

A special case of opacity is that involving metrical structure. For example, a stress rule may place stress on a vowel at some point in the derivation, after which a subsequent rule wipes out its context of application, for example by a metathesis of consonants which affects syllable weight $^{4}$. The example below illustrates this kind of interaction of stress and metathesis in Palestinian Arabic (Kenstowicz \& Kisseberth 1979). Stress is assigned to the penult if it is heavy (e.g. darásti 'you fem. studied'), and otherwise to the antepenult (e.g. dárasat 'she studied'). Metathesis, a rule restricted to stems ending in the sequence CCVC, renders the stress pattern opaque by closing the penult:

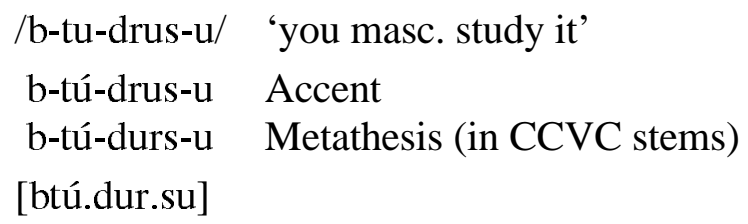

Opacity of metrical structure appears to make a very strong case for derivational theory. In Palestinian Arabic, as in many other languages, stress is a predictable property, reflecting a fully productive set of generalisations. It's context is created by syllabification, another fully predictable property. If the stress pattern reflects a syllable structure that coincides with the segmental structure of the lexical representation, but not with that of the surface form, then it seems almost forced to assume some intermediate level in the derivation at which stress is assigned. This level cannot coincide with the 'input' (since stress is fed by syllabification), nor with the 'output' (since syllabification may have changed at the surface).

Proponents of derivational theory have not failed to point out that opacity presents difficulties to theories that make alternative assumptions, such as Hooper's (1976) 'True Generalization Condition', according to which all rule must express surface generalisations. In the

\footnotetext{
${ }^{4}$ Some prosody-dependent processes actually destroy their own context of application. For example, foot-governed vowel deletion rules affect syllable structure, destroying their conditioning foot structure (see Kager 1997 for an approach in OT).
} 
seventies this issue lead to an intense debate in the phonological literature, until other issues became the focus of attention. But recently, 'opacity' has become a potential issue in phonology again, due to the rise of Optimality Theory (Prince \& Smolensky 1993). In a sense, OT itself is a logical development from the discussion on rule interactions in the seventies, specifically that on 'conspiracies'. It was first observed by Kisseberth (1970) that grammars (i.e. 'sets of rules') strongly favor rule interactions that produce specific output targets, or that avoid specific output characteristics. Such 'rule-conspiracies' were found in one language after another, and point to a serious flaw of derivational theory, whose basic tenet is that rules are output-blind.

OT views the output level as the 'priviliged' level at which significant linguistic generalisations are expressed. On the view that grammars map underlying representations (inputs) into surface forms (outputs), this reduces derivations to one-step mappings. Any differences between the input and output (effects of rule application in derivational theory) are due to universal well-formedness constraints that favor (or reject) output properties. Well-formedness constraints are always in competition with a second class of constraints, the so-called faithfulness constraints, which require that the input and output be identical (McCarthy \& Prince 1995). In a typical way, phonology (or language) is a conflict between 'contrast' and 'well-formedness'. The formal equivalent of the notion of 'conflict' in OT is constraint ranking: the best possible output form is the one that maximally satisfies higher ranked constraints, inherently at the expense of lower ranked ones. Much like derivational theory, OT finds its explanatory value in maximising the scope of linguistic generalisations. The difference between both theories resides in how interactions between generalisations take place: by linear precedence (derivational theory), or by hierarchical ranking (OT).

The cases of opacity that I have discussed under the headings of 'overapplication' and 'underapplication' pose challenges for Optimality Theory. These seem to require a level of generalisation that does not coincide with the input, nor the output. Intermediary levels of derivations are excluded by OT, under its most straightforward interpretation. Below we will see that it is actually possible to refer to a 'level' that does not occur with input, nor with output, nor with any intermediary level, but that is still independently motivated. This is the paradigm, the set of morphologically related forms whose output phonology can be taken as a basis of comparison. For example, we may say that a form $F$ has a property $P$ because there exists a morphologically related form $F$ ' that has this property $P$. In the example from Palestinian Arabic, finding such a related form is actually not difficult. The form btúdursu 'you masc. study it' is morphologically related to the form /b-tu-drus/ btúdrus 'you masc. study', which has stress on the 'corresponding' vowel [u]. Observe that the latter form can be viewed as the 'base' of the former in a 'compositional' way - in terms of its morpheme make up and the resulting feature composition.

The OT notion of faithfulness is generalised to cover not only identity relationships between input and output, but also between morphologically related output forms (Burzio 1994, McCarthy 1995, Benua 1995). Opacity, or 'under-application' and 'over-application' of phonology, can be said to be due to paradigm force: the domination of well-formedness constraints by paradigm identity constraints. The OT theory of 'opacity' therefore predicts that overapplication and underapplication always occur in the context of a morphologically related form that displays the relevant phonological property. Derivational theory makes no such prediction. A comparison of both theories should be based on various criteria, but the empirical investigation of this prediction should be among these criteria. This paper may in fact form a starting point.

This paper is organised as follows. In section 2, I will compare derivational theory and OT with respect to paradigmatic ('transderivational') relationships, on the basis of data from 
Palestinian Arabic that involve opacity of vowel deletion with respect to the surface stress pattern. I will propose a definition of 'paradigmatic relatedness' that predicts the morphological relationships under which two forms display phonological identity effects. A comparision is made with derivational theory, which uses the cycle rather than paradigmatic identity. Section 3 discusses base identity effects in Tripoli Arabic, another Levantine dialect. I focus on the possibility, allowed in OT, that a form's surface phonology reflects both 'faithfulness' constraints (input identity) and paradigmatic constraints (base identity). I will argue for parallel evaluation of output forms, in the sense that both base and lexical input are accessible simultaneously. Interactions between $\mathrm{I} / \mathrm{O}$ and $\mathrm{B} / \mathrm{O}$ faithfulness constraints are due to regular constraint ranking.

\section{The cycle vs. correspondence}

\subsection{Syncope in Palestinian Arabic}

In rule-based theory, transderivational relationships between morphologically related forms were in fact recognised. This notion is shaped as the transformational cycle (Chomsky \& Halle 1968), a mode of rule application in morphologically complex words. Ordered rules $\left(R_{1}-R_{n}\right)$ first apply to the minimal domain, and then to successively larger domains. Each language has a subset of rules that apply cyclically, and another set that apply noncyclically.

A famous example of cyclic rule application (again) comes from Palestinian Arabic, and it was pointed out by Brame (1974). The stress rule interacts with a rule of $i$-Syncope, that deletes /i/ in an open unstressed nonfinal syllable. It is stated below:

$$
\begin{aligned}
& \text { i-Syncope } \\
& \mathrm{i}[\text {-stress] } \rightarrow \varnothing \varnothing \quad / \quad \mathrm{CV}
\end{aligned}
$$

Since i-Syncope preserves stressed vowels, it must be ordered after stress. The stress rule of Palestinian Arabic (introduced informally above for example 3) places stress on a heavy penult, and otherwise on the antepenult. Verbal forms that are inflected for subject (person, number, and gender) illustrate the application of stress and i-Syncope:

\section{Verb plus subject suffix}

$\begin{array}{llll}\text { a. } & \text { /fihim/ } & & \text { 'to understand' (verb stem) } \\ \text { b.i } & \text { /fihim/ } & \text { fíhim } & \text { 'he understood' } \\ \text { b.ii } & \text { /fihim-na/ } & \text { fhím-na } & \text { 'we understood' } \\ \text { b.iii } & \text { /fihim-u/ } & \text { fíhm-u } & \text { 'they understood' }\end{array}$

Derivations of these forms are presented in (6):

$\begin{array}{llll} & \text { /fihim/ } & \text { /fihim-na/ } & \text { /fihim-u/ } \\ \text { Stress } & \text { fíhim } & \text { fihím-na } & \text { fíhim-u } \\ \text { i-Syncope } & --- & \text { fhím-na } & \text { fíhm-u } \\ & \text { [fíhim] } & \text { [fhím-na] } & \text { [fíhm-u }]\end{array}$

Verbal forms containing 'accusative' suffixes display transderivational preservation of stress. These forms are inflected for person, number, and gender of the object by a suffix that is added to a verb form inflected for subject. Observe that bold-face [i] in the forms in (7c) fails to delete, even though it stands in an open unstressed nonfinal syllable. 


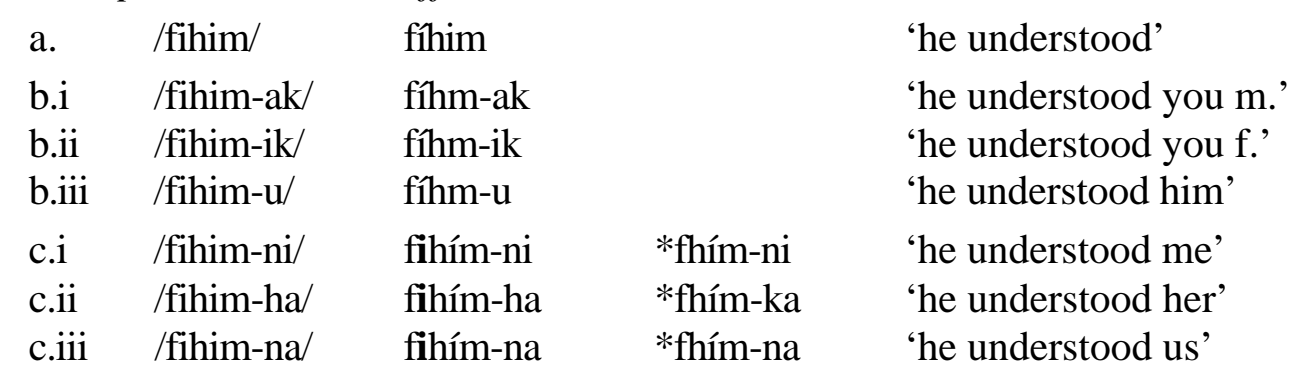

Brame observes that the accusative forms in which [i] fails to delete are all based on a free form (7a) in which [i] is stressed. The generalisation is that i-Syncope 'under-applies' to forms that have a morphological base form in which [i] is stressed.

The correctness of the generalisation is shown by possessives, which have morphologically related nouns in which the relevant [i] is stressed (Kenstowicz \& Abdul-Karim 1980):

Possessives
a. /birak/
bírak
b. /birak-u/
bírak-u
'pools'
c. /birak-na/
birák-na
'his pools'
*brák-na
'our pools'

Again, underapplication of i-Syncope correlates with the addition of a (possessive) suffix to a free form (or 'base') that is inflected itself.

Underapplication of i-Syncope cannot be due to an actual (secondary) stress on the initial syllable of accusatives and possessives, cf. [fìhím-na] and [bìrák-na]. Kenstowicz \& Abdul-Karim (1980) found that for speakers of Palestinian Arabic the analogous form that is based on a $\mathrm{CaCaC}$ verb, e.g. [ḍaráb-na], is ambiguous between 'we hit' and 'he hit us'. This makes the property that is responsible for blocking i-Syncope in accusatives and possessives 'abstract' to a certain degree.

In derivational theory the notion of 'relatedness' between forms is characteristically modelled in derivational terms, that is, cyclically. Brame (1974) assumes that accusatives and possessives have an additional internal layer of morphological structure, which triggers a cyclic application of the stress rule. The cyclically assigned stress on the first syllable of [fíhim] is carried over to the second cycle [[fihím]-na], even though it is subordinated to the new main stress. The secondary stress protects the initial syllable's vowel against postcyclic $i$-Syncope. Finally, initial secondary stress is erased by a postcyclic rule of Destressing:

\begin{tabular}{|c|c|c|c|c|}
\hline \multirow{2}{*}{\multicolumn{5}{|c|}{$[[\text { fihim }] \text { na }]_{\text {Acc }}\left[[[\text { fihim }] u]_{\text {Acc }}\right.$}} \\
\hline & & & & \\
\hline Stress & fihím-na & fíhim-u & fíhim & fíhim \\
\hline \multicolumn{5}{|l|}{ Cycle2 } \\
\hline Stress & --- & --- & fihím-na & (vacuous) \\
\hline \multicolumn{5}{|l|}{ Postcyclic } \\
\hline $\begin{array}{l}\text { i-Syncope } \\
\text { Destressing }\end{array}$ & $\begin{array}{c}\text { fhím-na } \\
\text { n.a. }\end{array}$ & $\begin{array}{l}\text { fíhm-u } \\
n . a .\end{array}$ & $\begin{array}{l}\text { blocked } \\
\text { fihím-na }\end{array}$ & $\begin{array}{c}\text { fíhm-u } \\
\text { n.a. }\end{array}$ \\
\hline Output & fhímna & fíhmu & fihímna & fíhmu \\
\hline
\end{tabular}


This analysis was regarded as strong evidence for extrinsic rule ordering, in the sense that a phonological property that is acquired in the course of the derivation (stress) blocks a rule that is sensitive to its presence (i-Syncope), although it is absent from the surface form due to a subsequent rule that deletes it (Destressing). This is achieved by linearly ordered rules that are 'blind' to underlying representations ('no globality'), and have access only to the representation that arises at the point in the derivation at which they apply.

How could this under-application of i-Syncope be analysed in OT, a theory that has no derivations, hence lacks a intermediary level of representation which Brame argued for? The central idea is that under-application is due to paradigm regularity. ${ }^{5}$ More specifically, a wellformedness constraint that militates against light syllables is dominated by an 'identity' constraint requiring that vowels which are 'prosodic heads' in basic forms should have 'correspondents' in morphologically related forms.

Let us first carefully consider the assumptions and general theoretical framework in which this analysis is embedded. Setting up identity constraints that compare the identity of morphologically related forms requires the notion of correspondence. McCarthy \& Prince (1995), in a work that introduces the notion, define it as a relationship between elements that are part of two strings. For example, between elements in an input string and elements in an output string:

\section{I/O correspondence}

Given two strings $S_{1}$ and $S_{2}$, correspondence is a relation $\Re$ from the elements of $S_{1}$ to those of $S_{2}$. Segments $\alpha$ (an element of an input string $S_{1}$ ) and $\beta$ (an element of an output string $S_{2}$ ) are referred to as correspondents of one another when $\alpha \Re \beta$.

Correspondence relationships hold between segments (an extension to prosodic elements is proposed by McCarthy 1995a). The actual constraints which produce faithfulness effects between Input and Output are of the types in (11):
a.
DEPENDENCE: Every element of $S_{2}$ has a correspondent in $S_{1}$.
b. MAXIMALITY: Every element of $S_{1}$ has a correspondent in $S_{2}$.
c. $\operatorname{IDENTITY}(\gamma F)$ : Let $\alpha$ be a segment in $S_{1}$ and $\beta$ be a correspondent of $\alpha$ in $\mathrm{S}_{2}$. If $\alpha$ is $[\gamma \mathrm{F}]$, then $\beta$ is $[\gamma \mathrm{F}]$.

In sum, a central assumption of Correspondence Theory is that constraint-based evaluation of an output form may have direct access to its input lexical representation. But this notion of correspondence has been generalised to relationships between an Output form and other Output forms. In particular, constraint evaluation of an output candidate may have access to the output of a morphologically related output form - its 'base'. This is so-called B/O-Correspondence (Benua 1995, McCarthy 1995a, Burzio 1994) ${ }^{6}$.

Benua (1995:51) argues for English that "Class 2 affixation is derived through an O/O correspondence with the unaffixed word." An example is a phonological process that is typical of New York-Philadelphia English: æ-Tensing in closed syllables, e.g. pass [pes], but passive

\footnotetext{
5 Since this paper was first presented (at the Tilburg conference "The derivational residue", fall 1995) two researchers have, independently, proposed a similar analysis of the Palestinian data: Kenstowicz (1995) and Steriade (1996). Moreover, Orgun (1996) has developed a declarative theory of cyclic phenomena that, in principle at least, offers an alternative approach to the data discussed here.

6 The terminology of 'base' has been chosen to reflect the strong similarities with other types of O/OCorrespondence, for example reduplication and truncation.
} 
[pæ.sıv]. In forms that contain Class 2 affixes, such as -ing, this 'overapplies' in the sense that the vowel in the open syllable of passing [pe.sin] surfaces as tense. Benua argues that this overapplication in passing is due to its relatedness to its base, pass [pes]. In a diagram, this can be portrayed as follows ('B' abbreviates the base, while 'A' abbrviates 'affixed form'):

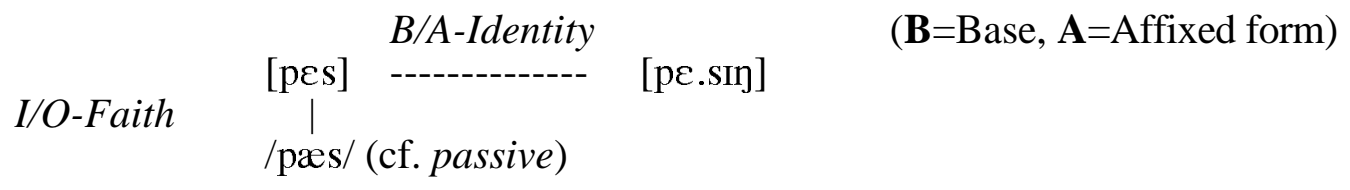

Two constraint interactions are relevant. First, the well-formedness constraint $* æ]_{\sigma}$ that rules out $[æ]$ in closed syllables outranks a well-formedness constraint *TENSE-low, requiring low vowels to be lax. This ranking is supported by the observation that [pes] is selected as the optimal candidate, rather than [pæs]. Second, the B/A-identity constraint with respect to the feature [tense] outranks *TENSE-low. This is supported by the selection of [pe.sin] rather than [pæ.sin].

Here and in the rest of this paper, I will use the notion of 'base' in a specific sense, namely as a form that is compositionally related to the affixed word in a morphological and a semantic sense. (The meaning of the affixed form must contain all grammatical features of its base.) Moreover, the base is a free form, i.e. a word. This second criterion implies that a base is always an output itself.

This definition of 'base' is precise enough to capture the distinction among verbal forms in Palestinian Arabic in the way that is required. Subject forms such as [fhimna] 'we understood' (5bii) have no base, since no free form occurs in the language that matches the criterion of semantic compositionality. In particular, the verb stem /fihim/, which would be appropriate in the compositional sense, fails to occur without inflection, failing the second criterion for 'base-hood'. Nor can the free form [fíhim] 'he understood' serve as a base, since this is not compositionally related to [fhimna] 'we understood'. In contrast, all object forms have a base by these criteria. For example, [fihimna] 'he understood us' has as its base the free form [fihim] 'he understood', of which it contains all grammatical features.

The generalisation is that i-Syncope 'underapplies' to vowels that are stressed in the base:

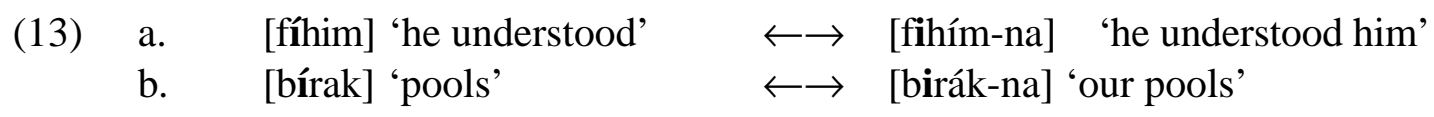

From here on I will use graphic means to indicate the correspondence relationships between an affixed form and (on the one hand) its input, and (on the other hand) its base. I will mark these relationships by vertical lines between correspondents at three levels (Input, Output, and base). In (14a), bold-face [i] indicates the underapplication of i-Syncope in the output:

\footnotetext{
a. 'he understood us'

/ f i him -n a /

$\|||||$

[ f i hím -n a ]

$\||| \mid$

[ fílh i m]

'he understood'
}

b. 'we understood'
/ f i h i m-n a /
$|+|||$
[ f hím-n a ]

Input

I/O Correspondence

Output

$B / O$ Correspondence

\section{Base}


The correspondence-based perspective of this pattern is that syncope 'underapplies' in the accusative and possessive because the relevant vowels have stressed correspondents in the base. This requires an extension of correspondence to stress properties of segments. Such an extension was proposed by McCarthy (1995a), Alderete (1995), and Kager (forthcoming):

HEAD-MAX(B/O)

Every segment in the base prosodic head has a correspondent in the output.

The effects of what I have called 'i-Syncope' so far are due to a well-formedness constraint that disallows [i] in open syllables ${ }^{7}$.

(16) No [i]

/i/ is not allowed in light syllables.

Note that no reference is made to stress, a result that will be confirmed in Section 2.2, where we discuss the interaction between syncope, stress and epenthesis.

No [i] obviously outranks the identity constraint requiring that input segments have correspondents in the output (cf. McCarthy \& Prince 1995):

$\operatorname{Max}(\mathrm{I} / \mathrm{O})$

Every segment in the input has a correspondent in the output.

This ranking is motivated by the fact that deletion is possible in forms such as [fhímna] 'we understood', which satisfy No [i] at the expense of MAX(I/O). The constraint ranking that now arises is (18):

$$
\operatorname{HEAD}-\mathrm{MAX}(\mathrm{B} / \mathrm{O}) \gg \mathrm{No}[\mathrm{i}] \gg \operatorname{MAX}(\mathrm{I} / \mathrm{O})
$$

The analysis is illustrated by the tableaux (19-20). Only candidates are considered that satisfy the canonical stress patterns of Palestinian Arabic; the issue of how stress is predictable by constraints, and its interaction with the processes of syncope and epenthesis will be taken up in section 2.2 below.

Tableau (19) illustrates the underapplication of i-syncope due to base identity, while tableau (20) shows how syncope occurs in a form that lacks a base:

\begin{tabular}{|lr||c|c|c|}
\hline (19) & $\begin{array}{l}\text { Input: /fihim, -na/ } \\
\text { Base: [fí.him] }\end{array}$ & HEAD-MAX(B/O) & No [i] & MAX(I/O) \\
\hline \hline a. & [fi.hím.na] & & $*$ & \\
\hline b. & [fhím.na] & $* !$ & & $*$ \\
\hline
\end{tabular}

\footnotetext{
7 This constraint is modelled after an analogous constraint No [a] in Orgun (1995). An interesting question is whether No [i] can be decomposed into general constraints which, taken together, produce its effects. I believe that this is possible, if we assume a constraint against monomoraic syllables (argued for by Broselow 1992:32), and rank this in between faithfulness constraints for specific vowels, e.g. IDENT-[a] » ${ }^{*} \sigma_{\mu} \gg$ IDENT-[i]. I will not pursue this issue here, and maintain the formulation of No [i] as it is.
} 


\begin{tabular}{|lr||c|c|c|}
\hline \begin{tabular}{ll|l|} 
(20) & Input: /fihim, -na/ \\
Base: none
\end{tabular} & HEAD-MAX(B/O) & No [i] & MAX(I/O) \\
\hline \hline a. & [fi.hím.na] & & $* !$ & \\
\hline b. & [fhím.na] & & & $*$ \\
\hline
\end{tabular}

Turning to the forms that have vowel-initial suffixes, we find that application of i-syncope is blocked in neither form.

\begin{tabular}{|lr||c|c|c|}
\hline$(21)$ & $\begin{array}{c}\text { Input: /fihim, -u/ } \\
\text { Base: [fí.him] }\end{array}$ & HEAD-MAX(B/O) & No [i] & MAX(I/O) \\
\hline \hline a. & [fí.hi.mu] & & $*$ !* & \\
\hline b. & & & & $*$ \\
\hline c. & [fíh.mu] & & $*$ & $*$ \\
\hline
\end{tabular}

\begin{tabular}{|lr||c|c|c|}
\hline$(22)$ & $\begin{array}{c}\text { Input: /fihim, }-\mathrm{u} / \\
\text { Base: } \text { none }\end{array}$ & HEAD-MAX(B/O) & No [i] & MAX(I/O) \\
\hline \hline a. & [fí.hi.mu] & & $*$ ! & \\
\hline b. & [fíh.mu] & & & $*$ \\
\hline c. & [fhí.mu] & & $* !$ & $*$ \\
\hline
\end{tabular}

If we compare this output-based analysis of (22) to the derivational analysis of such forms, we find that the latter analysis imposes a condition on i-Syncope that it applies in unstressed syllables. This condition protects the vowel in the initial syllable of (22) against i-Syncope, in order to rule out the incorrect form *[fhímu]. But in the OT analysis, no need arises for such a condition, and actually it would be impossible to state it. It is impossible to refer to lack of stress in the target vowel of syncope, since this vowel does not appear in the output. Nor is there an input correspondent that is stressed, and to which the blocking of syncope could be attributed through a 'faithfulness' constraint. But on the other hand, the OT analysis simply does without a condition on the stress value of the syncopated vowel. It blocks *[fhí.mu] by the very constraint that triggers syncope in the first place: No [i]. If the 'goal' of syncope is avoidance of light syllables containing [i], then it is preferrable to maximally achieve this goal in the output (cf. [fíh.mu], 22b), rather than succeeding only halfway (cf. 22c).

From the above discussion and analysis, a number of preliminary conclusions can be drawn. First, the notion of 'base' in B/O correspondence is firmly linked to compositionality. Second, the requirement that the base must be an output form correctly predicts that transderivational relationships must involve output forms. This prediction does not follow from derivational theory, since what counts as a cycle is inherently unconstrained by the criterion of 'occurrence as a free form'. In fact, any layer of morphological structure regardless of its relationship to word morphology is predicted to display cyclic properties. In order to obtain the relevant distinction between subject morphology and object morphology in Palestinian Arabic verbs, Brame had to make the arbitrary assumption that only the latter type involves cyclically layered structure. If matters had been reverse (with subject morphology invoking cyclic layering), this would have been equally natural on the derivational analysis. Third, the underapplication of a phonological 'process' is modelled as a domination of 'base identity' constraints over wellformedness constraints in the hierarchy. 


\subsection{Opacity of metrical structure due to i-Epenthesis}

We now turn to opacity of metrical structure, which arises by various modifications of the syllable structure on which stress is based. I will first discuss the process of epenthesis that is the main source of metrical opacity, and the way in which it is affected by base identity and faithfulness. Then I will discuss the metrical constraints proper, and rank them with respect to those responsible for vowel-zero alternations and base identity effects.

As the Levantine dialects to which it is related, Palestinian Arabic has a process of iEpenthesis, which inserts [i] between the first and second consonant in a sequence of three consonants, or between two consonants at the end of the word:

$$
\underset{\varnothing \rightarrow \mathrm{i} \text {-Epenthesis }}{\varnothing} \mathrm{C} \_\mathrm{C}\{\mathrm{C}, \#\}
$$

This process is the source of opaque stress in examples such as those in (24a.iii, b.iii) below:

$\begin{array}{lllll}\text { a.i } & / \text { fihm/ } & \text { fí.him } & & \text { 'understanding' } \\ \text { a.ii } & \text { /fihm-u/ } & \text { fíh.mu } & & \text { 'his understanding' } \\ \text { a.iii } & \text { /fihm-na/ } & \text { fí.him.na } & * \text { fi.hím.na } & \text { 'our understanding' } \\ \text { b.i } & / \text { Rakl/ } & \text { Pá.kil } & & \text { 'food' } \\ \text { b.ii } & / \text { Rakl-u/ } & \text { Pák.lu } & & \text { 'his food' } \\ \text { b.iii } & \text { /Rakl-ha/ } & \text { Pá.kil.ha } & \text { *2a.kíl.ha } & \text { 'her food' }\end{array}$

In a derivational analysis, this interaction involves ordering i-Epenthesis after stress. Cyclic application of stress is essentially irrelevant to its interaction with epenthesis, but for reasons of similarity to earlier derivations I have indicated it in the derivations below:

$\begin{array}{clll} & \text { /fihm/ } & \text { /fihm-u/ } & \text { /fihm-na/ } \\ \text { Stress Cycle 1 } & \text { fíhm } & \text { fíhm } & \text { fíhm } \\ \text { Cycle 2 } & \text { fíhm } & \text { fíhm-u } & \text { fíhm-na } \\ \text { i-Epenthesis } & \text { fíhim } & --- & \text { fíhim-na } \\ & \text { [fíhim] } & \text { [fíhmu] } & \text { [fíhimna] }\end{array}$

Again the question arises as to how OT captures the opacity. Let us first see what constraint interaction produces i-epenthesis.

A 'repair' in the form of vowel epenthesis is triggered by a combination of two highranked constraints on syllable well-formedness $(26 \mathrm{a}, \mathrm{b})$, which I will combine into a cover constraint *CLUSTER:

\section{*CLUSTER}

a. *COMPLEX-OnSET (cf. Prince \& Smolensky 1993)

No complex syllable onsets.

b. SONORITY SEQUENCING PRINCIPLE (cf. Clements 1990)

Segments of higher ranking sonority stand closer to the centre of the syllable than segments of lower ranking sonority. 
Avoidance of syllabic ill-formedness takes priority over avoidance of epenthetic vowels. Or, to put it into terms of constraint ranking: *CLUSTER » DEP $(\mathrm{O} / \mathrm{I})^{8}$.

Violations of ${ }^{*}$ CLUSTER can be avoided in two different ways, that is, by epenthesis between the first and the second consonant, or after the second consonant.

$$
\begin{array}{llr}
\text { a. } & \text { C_CC } & \text { fí.him.na } \\
\text { b. } & \text { CC_C } & \text { *fíh.mi.na }
\end{array}
$$

In a derivational analysis, the locus of epenthesis is stated in the rule, or derived indirectly by a statement that epenthesis applies directionally (cf. Itô 1989). But neither of these options is available in an OT analysis. Once more, base identity seems to be involved. If we consider the output form [fí.him.na], we find that this maximally resembles the base in the sense that the vowels that appear in the base [fí.him] are both preserved in the output. The fact that in (28b) the underlined vowel is 'epenthetic' with respect to the input is totally irrelevant for base identity:
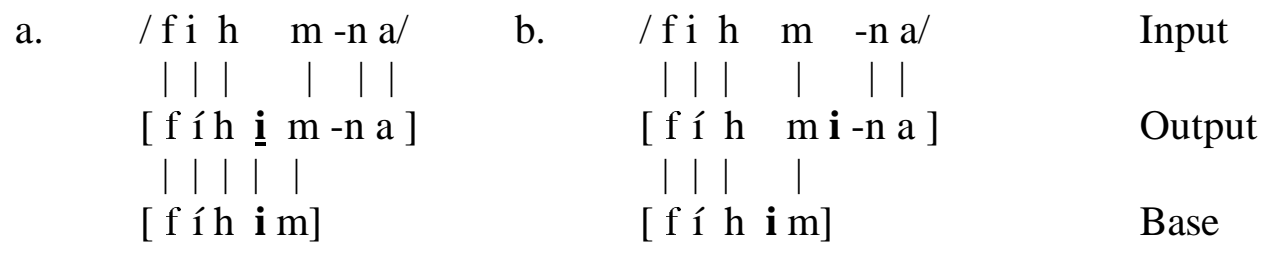

Correspondence between base and output is broken in $(28 \mathrm{~b})$, where the epenthetic vowel has no correspondent in the base. This points to the following base-identity constraint requiring that base segments have correspondents in the output:

\section{$\operatorname{MAX}(\mathbf{B} / \mathbf{O})$}

Every segment in the base has a correspondent in the output.

This constraint is more general that $\operatorname{HEADMAX}(\mathrm{B} / \mathrm{O})$, since it does not mention the stressed status of the vowel in the base. $\operatorname{MAX}(\mathrm{B} / \mathrm{O})$ is also distinguished from $\operatorname{HEADMAX}(\mathrm{B} / \mathrm{O})$ in its position in the constraint hierarchy, specifically with respect to No [i]. While the latter must be ranked above No [i], the former ranks below it, as the following syncope data show:
a. $\operatorname{HeadMax}(\mathrm{B} / \mathrm{O}) \gg \mathrm{No}[\mathrm{i}]$
/fihim-na/ 'he understood us'
[fihím-na] > [fhím-na]
b. $\quad \mathrm{No}[\mathrm{i}] \gg \operatorname{MAX}(\mathrm{B} / \mathrm{O})$
/fihim-u/ 'he understood him'
[fíhm-u] > [fíhim-u]

The next question is: if the locus of epenthesis in [fi.him.na] 'our understanding' depends on that in its base [fí.him] 'understanding', then what predicts the epenthesis site in the base? Here we must consider two candidates, one with stem-internal epenthesis, [fí.him], the other with stemexternal epenthesis, [fíh.mi]. The former is selected by a well-known generalised alignment constraint (McCarthy \& Prince 1993):

\footnotetext{
${ }^{8}$ Notice that at the word beginning, complex onsets are allowed, and actually created by the deletion of input vowels (cf. [fhím-na]).
} 


$$
\begin{aligned}
& \text { Align-R } \\
& ]_{\text {Stem }}=\right]_{\sigma}
\end{aligned}
$$

This constraint is undominated in Palestinian Arabic, as far as I can determine.

In correspondence theory, what it means for [i] to be the epenthetic vowel is a matter of strictness of 'identity' between an output vowel and its input correspondents. That is, it is 'less costly' to have [i] as an output vowel lacking an input correspondent, than it is to have any other vowel in such a situation. This result follows from the ranking of the O/I-Identity constraint IDENT-[a] at the top of the constraint hierarchy, guaranteeing that every surface [a] has an input correspondent. Accordingly, the choice of epenthetic vowel is restricted to [i] (and possibly [u $]^{9}$ ). See (32):
a. IDENT-[a] $(\mathrm{O} / \mathrm{I})$
Output [a] must have an input correspondent.
b. IDENT-[a] » IDENT-[i], IDENT-[u]

In the tableaux below, I will not include this ranking, and tactitly assume it by including only [i] as an epenthetic vowel.

We are now in a position to localise the source of metrical opacity. In Palestinian Arabic, heavy penultimate syllables are stressed in the 'regular' case. Then why is epenthetic [i] in [fí.him.na] and [?á.kil.ha] unstressed even though it stands in a closed penult? Actually the rejection of stress by epenthetic vowels is a cross-linguistically common phenomenon (cf. Piggott 1995, Alderete 1995). Accordingly, Alderete (this volume) proposes a constraint to the effect that stressed vowels must have input correspondents:

HEAD-DEP(O/I)

Every vowel in the output prosodic head has a correspondent in the input.

Epenthetic $\mathbf{i}$ in [fí.him.na] lacks a correspondent in the input, as illustrated by the diagram in (34a). Therefore stressing it would violate $\operatorname{HEAD}-\operatorname{DEP}(\mathrm{O} / \mathrm{I})$. In contrast, the stressed vowel in [ba.kár.na] 'our cattle' (34b), with a base [bá.kar] 'cattle', has an input correspondent and hence stressing it does not violate HEAD-DEP(O/I).
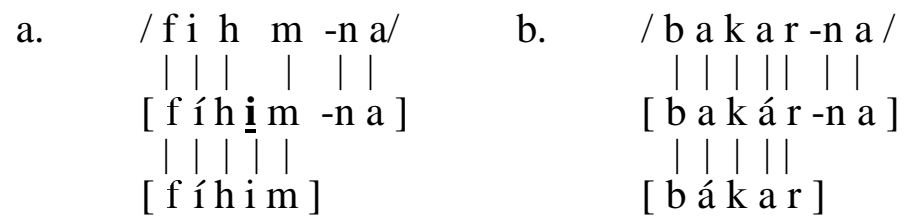
Input
Output
Base

Indirectly, form (34b) rules out an alternative hypothesis about opaque stress in [fí.him.na], according to which a vowel that is stressed in the output must have a stressed correspondent in the base. This hypothesis is ruled out since the stressed output vowel of form (38b) has no stressed correspondent in the base.

'Metrical opacity' is modelled as a domination of an identity constraint over a wellformedness constraint. Here $\operatorname{HEAD}-\operatorname{DEP}(\mathrm{O} / \mathrm{I})$ dominates the well-formedness constraint that is

\footnotetext{
${ }^{9}$ See Abu-Salim (1980) for data showing that [u] patterns much like [i] in syncope and epenthesis.
} 
responsible for stress on heavy (penultimate) syllables (the Weight-to-Stress Principle, or WSP, Prince \& Smolensky 1993; more will be said about this constraint directly below):

$$
\operatorname{HEAD}-\mathrm{DEP}(\mathrm{O} / \mathrm{I}) \quad \gg \quad \text { WSP }
$$

The reverse ranking would produce penultimate stress, e.g. *[tifíl-na], rather than [tífil-na]. I rank HEAD-DEP(O/I) directly above WSP, postponing arguments for this ranking to section 3 .

Before I discuss the actual metrical constraints in Section 2.3, I will first demonstrate the analysis of vowel-zero alternations that we have available now by three tableaux of the minimal contrasts in [fihím-na] 'he understood us' (40), [fhím-na] 'we understood' (41), and [fíhim-na] 'our understanding' (42).

\begin{tabular}{|lc||c:c|c|c|c|c|}
\hline$(40)$ & $\begin{array}{l}\text { I: /fihim-na/ } \\
\text { B: }[\text { fí.him] }\end{array}$ & $\begin{array}{c}* \text { COM- } \\
\text { PLEX }\end{array}$ & $\begin{array}{c}\text { HEAD- } \\
\text { MAX(B/O) }\end{array}$ & No [i] & $\begin{array}{c}\text { HEAD- } \\
\text { DEP(O/I) }\end{array}$ & $\begin{array}{c}\text { MAX } \\
\text { (B/O) }\end{array}$ & WSP \\
\hline \hline a. & [fi.hím.na] & & & $*$ & & & \\
\hline b. & [fí.him.na] & & & $*$ & & & $* !$ \\
\hline c. & [fíh.mi.na] & & & $*$ & & $* !$ & \\
\hline d. & [fhím.na] & & $* !$ & & & $*$ & \\
\hline e. & [fíhm.na] & $* !$ & & & & $*$ & \\
\hline
\end{tabular}

\begin{tabular}{|c|c|c|c|c|c|c|c|}
\hline (41) & $\begin{array}{l}\text { I: /fihim-na/ } \\
\text { B: none }\end{array}$ & $\begin{array}{l}* \text { COM- } \\
\text { PLEX }\end{array}$ & $\begin{array}{c}\text { HEAD- } \\
\text { MAX }(B / O)\end{array}$ & No [i] & $\begin{array}{c}\text { HEAD- } \\
\operatorname{DEP}(\mathrm{O} / \mathrm{I})\end{array}$ & $\operatorname{MAX}(\mathrm{B} / \mathrm{O})$ & WSP \\
\hline a. & [fi.hím.na] & & & $* !$ & & & \\
\hline b. & [fí.him.na] & & & $* !$ & & & * \\
\hline c. & [fíh.mi.na] & & & $* !$ & & & \\
\hline d. & 咹 [fhím.na] & & & & & & \\
\hline e. & [fíhm.na] & $* !$ & & & & $*$ & \\
\hline
\end{tabular}

\begin{tabular}{|lc||c:c|c:c|c|c|}
\hline$(42)$ & $\begin{array}{c}\text { I: /fihm-na/ } \\
\text { B: [fí.him] }\end{array}$ & $\begin{array}{c}* \text { COM- } \\
\text { PLEX }\end{array}$ & $\begin{array}{c}\text { HEAD- } \\
\text { MAX(B/O) }\end{array}$ & No [i] & $\begin{array}{c}\text { HEAD- } \\
\text { DEP(O/I) }\end{array}$ & MAX(B/O) & WSP \\
\hline \hline a. & [fi.hím.na] & & & $*$ & $* !$ & & \\
\hline b. & & & & $*$ & & & $*$ \\
\hline c. [fí.him.na] & [fíh.mi.na] & & & $*$ & & $* !$ & \\
\hline d. & [fhím.na] & & $* !$ & & & $*$ & \\
\hline e. & [fíhm.na] & $* !$ & & & & $*$ & \\
\hline
\end{tabular}

Finally we are in a position to substantiate the claim that stress opacity of Palestinian Arabic involves the parallel evaluation of faithfulness ('input-identity') and paradigm regularity ('baseidentity'). Parallellism is demonstrated by the activity, within the same constraint hierarchy, of constraints evaluating $\mathrm{I} / \mathrm{O}$ correspondence and $\mathrm{B} / \mathrm{O}$ correspondence. Note that within one output form [fí.him.na] (42), the boldface vowel is treated as epenthetic with respect to the input (which is why it cannot surface as stressed - HEAD-DEP(O/I)), while it is paradoxically treated as nonepenthetic with respect to the base (which is why it must be retained - due to $\operatorname{MAX}(\mathrm{B} / \mathrm{O})$ ). 


\subsection{The stress pattern of Palestinian Arabic}

In order to fathom to which extent metrical constraints are subordinated to correspondence constraints, we must now take a closer look at the Palestinian Arabic stress system. Section 2.4 will integrate these constraints with the correspondence constraints of Section 2.2.

Main stress falls on the penultimate syllable if it is heavy, otherwise on the antepenult (as in Latin, the difference being that final 'superheavy' syllables may be stressed, see 43e).

\begin{tabular}{|c|c|c|c|}
\hline a. & $\begin{array}{l}\text { dá.rab } \\
\text { báa.rak } \\
\text { cál.lam }\end{array}$ & $\begin{array}{l}\text { 'he hit' } \\
\text { 'he blessed' } \\
\text { 'he taught' }\end{array}$ & $\begin{array}{l}(\mathrm{K} 207) \\
(\mathrm{K} 207) \\
(\mathrm{K} 207)\end{array}$ \\
\hline b. & $\begin{array}{l}\text { dá.ra.bu } \\
\text { dá.ra.sat } \\
\text { Cál.la.mu } \\
\text { báa.ra.ku }\end{array}$ & $\begin{array}{l}\text { 'they hit' } \\
\text { 'she studied' } \\
\text { 'they taught' } \\
\text { 'they blessed' }\end{array}$ & $\begin{array}{l}\text { (K 207) } \\
(\mathrm{K} \& \mathrm{~K} 230) \\
(\mathrm{K} 207) \\
(\mathrm{K} 207)\end{array}$ \\
\hline c. & $\begin{array}{l}\text { da.rá.sa.tu } \\
\text { baa.rá.ka.tu } \\
\text { Gal.lá.ma.tu }\end{array}$ & $\begin{array}{l}\text { 'she studied it' } \\
\text { 'she blessed him' } \\
\text { 'she taught him' }\end{array}$ & $\begin{array}{l}\text { (K\&K 230) } \\
\text { (K 207) } \\
\text { (K 207) }\end{array}$ \\
\hline d. & $\begin{array}{l}\text { da.rás.ti } \\
\text { Pa.zúu.ru } \\
\text { dar.bát.na } \\
\text { baa.ra.kát.na }\end{array}$ & $\begin{array}{l}\text { 'you fem. studied' } \\
\text { 'I visit him' } \\
\text { 'she hit us' } \\
\text { 'she blessed us' }\end{array}$ & $\begin{array}{l}(\mathrm{K} \& \mathrm{~K} 229) \\
(\mathrm{K} \& \mathrm{~K} 229) \\
(\mathrm{K} 207) \\
(\mathrm{K} 207)\end{array}$ \\
\hline e. & $\begin{array}{l}\text { da.rást } \\
\text { ka.máan }\end{array}$ & $\begin{array}{l}\text { 'I studied' } \\
\text { 'also' }\end{array}$ & $\begin{array}{l}\text { (K\&K 229) } \\
\text { (K\&K 229) }\end{array}$ \\
\hline
\end{tabular}

According to (Kenstowicz 1983:208), "reliable judgments of secondary stress are difficult to obtain." Apparently there is no secondary stress in immediately pretonic position ${ }^{10}$. This I attribute to an undominated constraint *CLASH.

\section{*Clash}

No adjacent syllables are stressed.

This accords with the rule of prestress destressing in Kenstowicz $(1983)^{11}$.

The foot of Palestinian is the quantitative or moraic trochee (McCarthy 1979, Hayes 1995) - (LL) or (H). With Dresher \& Lahiri (1991) and Kiparsky (1995), I assume that a third foot is universally analyseable as a moraic trochee, i.e. the 'resolved' foot $(\mathbf{L H})$ that is composed of a light plus heavy sequence. Evidence for $(\mathbf{L H})$ as a unit that is quantitatively equivalent to $(\mathbf{H})$ and (LL) comes from Old English (cf. Dresher \& Lahiri 1991), where high vowels were deleted that immediately followed precisely these three quantitative sequences, but not any other sequence, such as $\mathrm{HL}$ or $\mathrm{HH}$ :

${ }^{10}$ This is diagnosed by the fact that in long vowels in pretonic shorten (Abu-Salim 1983):

(i) a. báab 'door' c. ma.káa.tib 'offices'

b. bab-éen 'two doors' d. ma.ka.tíb.na 'our offices'

In the Tripoli dialect, to be discussed in Section 3, an analogous process occurs by which /a/ reduces to [i] in unstressed syllables. Again, reduction applies to pretonic heavy syllables (Kenstowicz \& Abu-Karim 1980).

${ }^{11}$ Kenstowicz \& Abdul-Karim (1980) assume that all non-primary stresses are suppressed by a rule of stress deletion. 

a. 'Pure'
(H)
(LL)
[(wór).du] [(wé.ru).du]

but $\operatorname{not}^{*}(\mathbf{H L})$

b. 'Resolved' (LH)

[(níi).(tè.nu)]

but $\operatorname{not}^{*}(\mathbf{H H})$

[(fæ.rel).du $]$

[(fúl).(wìh).tu]

This resolved foot occurs under duress, and is involved in 'opaque stress', as will be shown below. These three feet are precisely the feet that occur extensively in Arabic morphology (McCarthy \& Prince 1990).

Accordingly, I assume a high-ranking constraint FOOT-FORM:

\section{(46) FOOT-FORM}

Feet are moraic trochees $(\mathrm{H}),(\mathrm{LL})$ or $(\mathrm{LH})$.

The fact that the resolved foot $(\mathbf{L H})$ is observeable only under 'special' conditions is due to the Weight-to-Stress Principle (Prince \& Smolensky 1993):

\section{WSP}

Heavy syllables are prominent within the foot and on the grid.

The WSP is the constraint responsible for stress on heavy penults, e.g. [da.(rás).ti], rather than [(dá.ras).ti].

In surface forms of Palestinian Arabic, stress always appears on one of the final three syllables of the word (Kenstowicz 1983:207). Independent evidence bearing on this (cited by Kenstowicz) is the fact that English words ending in four light syllables are mispronounced so as to match the window requirement, e.g. necéssary, obligátory ${ }^{12}$. Antepenultimate stress in words ending in two or more light syllables is due to NONFINALITY:

\section{NONFINALITY}

The head of the PrWd must not be final.

According to Prince \& Smolensky (1993), who argue for NonFinALITY on the basis of the Latin stress pattern, it serves two purposes. First, the final syllable must not be the head of the main stress foot, and second, the final syllable must not be part of the main stress foot ('no final foot'). Violations are counted separately for these two requirements.

\begin{tabular}{|c|c|c|c|c|c|c|}
\hline (49) & I: /darasat/ & $*$ CLASH & $\begin{array}{l}\text { FOOT- } \\
\text { FORM }\end{array}$ & $\begin{array}{c}\text { NON- } \\
\text { FINALITY }\end{array}$ & WSP & $\begin{array}{c}\text { PARSE- } \\
\sigma\end{array}$ \\
\hline a. & [(dá.ra).sat] & & & & * & $*$ \\
\hline b. & [da.(rá.sat)] & & & $* !$ & $*$ & * \\
\hline c. & [da.ra.(sát)] & & & $* ! *$ & & $* *$ \\
\hline d. & [(dá.ra).(sát)] & & & $* ! *$ & & \\
\hline
\end{tabular}

12 The Palestinian speaker consulted by Halle \& Kenstowicz (1989) produced initial stress in Classical Arabic forms such as [〕ájaratun] 'a tree', which apparently argues against a trisyllabic window. However, the argument is flawed by the fact that this form in all respects (including stress) matches the classical language. Presumably any educated speaker would know the classical pronunciation. 


\begin{tabular}{|c|c|c|c|c|c|c|}
\hline (50) & I: /baarak/ & $*$ CLASH & $\begin{array}{l}\text { FOOT- } \\
\text { FORM }\end{array}$ & $\begin{array}{l}\text { NON- } \\
\text { FINALITY }\end{array}$ & WSP & $\begin{array}{c}\text { PARSE- } \\
\sigma\end{array}$ \\
\hline & [(báa).rak] & & & & $*$ & $*$ \\
\hline b. & [baa.(rák)] & & & $* ! *$ & $*$ & $*$ \\
\hline c. & [(báa.rak)] & & $* !$ & $*$ & $*$ & \\
\hline d. & [(bàa).(rák)] & $* !$ & & $* *$ & & \\
\hline
\end{tabular}

For CvCvC words NonFinALITY forces a $(\mathrm{LH})$ trochee:

\begin{tabular}{|lc||c:c|c|c:c|}
\hline$(51)$ & I: /darab/ & $*$ CLASH & $\begin{array}{c}\text { FOOT- } \\
\text { FORM }\end{array}$ & $\begin{array}{c}\text { NON- } \\
\text { FINALITY }\end{array}$ & WSP & $\begin{array}{c}\text { PARSE- } \\
\sigma\end{array}$ \\
\hline \hline a. & & & $*$ & $*$ & \\
\hline b. & {$[$ dá.rab)] } & & & $*$ & & $*$ \\
\hline c. & [da.(ráb)] & & & $* * !$ & & $*$ \\
\hline
\end{tabular}

But NONFINALITY is insufficient to predict stress in words that end in three or more light syllables, such as [da.(rá.sa).tu]. This is due to PARSE-2 (Kager 1994):

\section{(52) PARSE-2}

One of two adjacent syllables must be stressed.

For reasons that will become clear immediately below, PARSE- 2 must be ranked below NONFINALITY, but above WSP. The tableau in (53) shows how antepenultimate stress is predicted in [da.(rá.sa).tu]:

\begin{tabular}{|c|c|c|c|c|c|c|c|}
\hline (53) & I: /darasatu/ & *CLASH & $\begin{array}{l}\text { FOOT- } \\
\text { FORM }\end{array}$ & $\begin{array}{c}\text { NON- } \\
\text { FINALITY }\end{array}$ & PARSE-2 & WSP & $\begin{array}{c}\text { PARSE- } \\
\sigma\end{array}$ \\
\hline a. & 吼 [da.(rá.sa).tu] & & & & & & *** \\
\hline b. & [(dá.ra).sa.tu] & & & & $* !$ & & $* *$ \\
\hline c. & [da.ra.(sá.tu)] & & & $* !$ & $*$ & & $* *$ \\
\hline d. & [(dà.ra).(sá.tu)] & & & $* !$ & & & \\
\hline
\end{tabular}

The next tableau shows why PARSE-2 must dominate WSP:

\begin{tabular}{|c|c|c|c|c|c|c|c|}
\hline (54) & I: /baarakatu/ & *CLASH & $\begin{array}{l}\text { FOOT- } \\
\text { FORM } \\
\end{array}$ & $\begin{array}{c}\text { NON- } \\
\text { FINALITY }\end{array}$ & PARSE- 2 & WSP & $\begin{array}{c}\text { PARSE- } \\
\sigma \\
\end{array}$ \\
\hline & 呼 [baa.(rá.ka).tu] & & & & & $*$ & $* *$ \\
\hline b. & [(báa).ra.ka.tu] & & & & $* ! *$ & & $* * *$ \\
\hline c. & [(bàa).ra.(ká.tu)] & & & $* !$ & & & $*$ \\
\hline d. & [(bàa).(rá.ka).tu] & $* !$ & & & & & $*$ \\
\hline
\end{tabular}

With undominated FOOT-FORM, ruling out (HL) trochees, PARSE-2 is necessarily dominated by NONFINALITY. 


\begin{tabular}{|lr||l|c|c|c|c|c|}
\hline (55) & I: /baaraku/ & $*$ CLASH & $\begin{array}{c}\text { FOOT- } \\
\text { FORM }\end{array}$ & $\begin{array}{c}\text { NON- } \\
\text { FINALITY }\end{array}$ & PARSE-2 & WSP & $\begin{array}{c}\text { PARSE- } \\
\sigma\end{array}$ \\
\hline \hline a. & & & & $*$ & & $* *$ \\
\hline b. & [(báa).ra.ku] & & & & & $*$ & $*$ \\
\hline c. & [baa.(rá.ku)] & & & $* !$ & & & $*$ \\
\hline d. & [(báa.ra).ku] & & $* !$ & & & & \\
\hline
\end{tabular}

Forms such as [da.(rás).ti] show that WSP must dominate PARSE- $\sigma$ :

\begin{tabular}{|lr||l|c|c|c|c|c|}
\hline$(56)$ & I: /darasti/ & $*$ CLASH & $\begin{array}{c}\text { FOOT- } \\
\text { FORM }\end{array}$ & $\begin{array}{c}\text { NON- } \\
\text { FINALITY }\end{array}$ & PARSE-2 & WSP & $\begin{array}{c}\text { PARSE- } \\
\sigma\end{array}$ \\
\hline \hline a. & & & & & & $* *$ \\
\hline b. & [da.(rás).ti] & & & & & $* !$ & $*$ \\
\hline c. & [dá.ras).ti] & & & & & & \\
\hline
\end{tabular}

In [dar.(bát).na] two undominated constraints (*CLASH and FOOTFORM) force a parsing in which one of the heavy syllables is outside the foot. The choice which one is unstressed (and which one is stressed) is made by PARSE-2:

\begin{tabular}{|lr||l|l|c|c|c|c|}
\hline (57) & I: /darbatna/ & $*$ CLASH & $\begin{array}{c}\text { FOOT- } \\
\text { FORM }\end{array}$ & $\begin{array}{c}\text { NON- } \\
\text { FINALITY }\end{array}$ & PARSE-2 & WSP & $\begin{array}{c}\text { PARSE- } \\
\sigma\end{array}$ \\
\hline \hline a. & & & & & $*$ & $* *$ \\
\hline b. & [dar.(bát).na] & & & & $* !$ & $*$ & $* *$ \\
\hline c. & [(dár).bat.na] & & & & & $*$ & $*$ \\
\hline d. & [(dár.bat).na] & & $* !$ & & & $*$ \\
\hline
\end{tabular}

Words ending in $\mathrm{CvvC \#}$ and $\mathrm{CvCC} \#$ are stressed on their final syllables. Kenstowicz (1986) argues that the final consonant in these sequences is extraprosodic, that is, outside the syllable. The preceding syllable may thus satisfy NONFINALITY if stressed (Hayes 1995).

\begin{tabular}{|c|c|c|c|c|c|c|c|}
\hline$(58)$ & I: /darast/ & $*$ CLASH & $\begin{array}{l}\text { FOOT- } \\
\text { FORM }\end{array}$ & $\begin{array}{c}\text { NON- } \\
\text { FINALITY }\end{array}$ & PARSE-2 & WSP & $\begin{array}{c}\text { PARSE- } \\
\sigma\end{array}$ \\
\hline a. & u电 [da.(rás).t] & & & & & & $*$ \\
\hline b. & [(dá.ras).t] & & & & & $* !$ & \\
\hline
\end{tabular}
below:

A summary of rankings and an illustration by some forms on which they are based is given
a.i * $\mathrm{CLASH} » \mathrm{WSP}$
a.ii *CLASH $\gg$ PARSE- $\sigma$
[dar.(bát).na]
[(dàr).(bát).na]
b.i
FOOT-FORM » NONFINALITY [(dá.rab)]
b.ii FOOT-FORM » PARSE-2
[(mák).ta.bi]
b.iii FOOT-FORM »WSP
[(dá.rab)]
b.iv FOOT-FORM $»$ PARSE- $\sigma$
[dar.(bát).na]

$\begin{array}{ll}> & {[(\text { dàr}) \cdot(\text { bát }) \cdot n a]} \\ > & {[(\text { dàr }) \cdot(\text { bát }) \cdot n a]} \\ > & {[(\text { dá).rab }]} \\ > & {[(\text { mák.ta).bi }]} \\ > & {[(\text { da.ráb })]} \\ > & {[(\text { dár.bat }) \cdot n a]}\end{array}$




\begin{tabular}{|c|c|c|c|c|}
\hline c.i & NONFINALITY »PARSE-2 & [(mák).ta.bi] & $>$ & [mak.(tá.bi)] \\
\hline c.ii & NONFINALITY » WSP & [(dá.rab)] & $>$ & [da.(ráb)] \\
\hline c.iii & NONFINALITY »PARSE- $\sigma$ & [(mák).ta.bi] & $>$ & [mak.(tá.bi)] \\
\hline d. & PARSE- $2 \gg \mathrm{WSP}$ & [baa.(rá.ka).tu] & $>$ & [(báa).ra.ka.tu] \\
\hline e. & $\mathrm{WSP} \gg \mathrm{PARSE}-\sigma$ & [da.(rás).ti] & $>$ & [(dá.ras).ti] \\
\hline
\end{tabular}

These rankings of individual constraints are integrated into the total ranking below:

$$
\text { *CLASh, FoOt-Form } » \text { NonFinality } \gg \text { PARSE- } 2 » \text { WSP } \gg \text { PARSE- } \sigma
$$

\subsection{Integrating the metrical constraints and the correspondence constraints}

What remains to be demonstrated is that the metrical constraints of the previous section can be integrated into a total ranking together with the correspondence constraints that I argued for in Section 2.2 on the basis of vowel-zero alternations and identity effects. The hierarchy that was reached at the end of Section 2.2 is repeated below:

$$
\text { *Cluster, Head-Max(B/O) » No [i], Head-DeP(O/I) » Max(B/O), WSP }
$$

Factoring out the undominated constraints from both hierarchies (the metrical hierarchy and 61), we find that we face the task of integrating the following two partial rankings:

$$
\begin{array}{ll}
\text { a. } & \text { NONFINALITY } » \text { PARSE- } 2 ~ » \text { WSP } » \text { PARSE- } \sigma \\
\text { b. } & \text { No }[\mathrm{i}], \operatorname{HEAD}-\operatorname{DEP}(\mathrm{O} / \mathrm{I}) » \operatorname{MAX}(\mathrm{B} / \mathrm{O}) \text {, WSP }
\end{array}
$$

An interesting aspect of this task is the fact that vowel-zero alternations may be partially conditioned by metrical constraints. That is, the (non-)application of syncope and epenthesis strives towards specific metrical targers in the output.

For instance, consider the fact that in syncope is blocked in the first vowel in /fihim/ (*[(fhím)]), even though this would satisfy No [i]. This candidate is rejected by a metrical constraint, viz. NONFINALITY. Formally this means that NONFINALITY dominates No [i], as in (63). We have seen no evidence (yet) to rank No [i] with respect to PARSE-2 and HEAD-DEP(O/I), nor to rank $\operatorname{MAX}(\mathrm{B} / \mathrm{O})$ with respect to WSP:

\begin{tabular}{|lc||c|c:c:c|c:c|c|}
\hline$(63)$ & $\begin{array}{c}\text { I: /fihim/ } \\
\text { B: none }\end{array}$ & $\begin{array}{c}\text { NON- } \\
\text { FINALITY }\end{array}$ & $\begin{array}{c}\text { No } \\
{[\mathrm{i}]}\end{array}$ & $\begin{array}{c}\text { PARSE } \\
-2\end{array}$ & $\begin{array}{c}\text { HEAD- } \\
\text { DEP(O/I) }\end{array}$ & $\begin{array}{c}\text { MAX } \\
\text { (B/O) }\end{array}$ & WSP & $\begin{array}{c}\text { PARSE } \\
-\sigma\end{array}$ \\
\hline \hline a. & {$[($ fí.him $)]$} & $*$ & $*$ & & & & $*$ & \\
\hline b. & {$[$ (fhím)] $]$} & $* * !$ & & & & & & \\
\hline
\end{tabular}

Another illustration of metrical conditioning of vowel-zero alternations is that of imperfect verbs with the input shape /yi-CCvC-v/, such as /yi-ktib-u/ [yí.kit.bu] 'they write'. Here i-Syncope interacts with i-Epenthesis in a very interesting way. The deletion of /i/ in an open syllable is compensated for by epenthesis of [i], thus avoiding syllable ill-formedness. Observe that it would apparently have been more 'economic' to retain the input vowel in its proper position (*[yík.ti.bu]), rather than to syncopate it, only to substitute another [i] by epenthesis. (This interaction has been called 'promiscuous syncope' by Broselow 1992). The interaction of syncope 
and epenthesis produces a striking confirmation of the sub-ranking of PARSE-2, HEAD-DEP(O/I) » WSP, which was originally motivated for stress 'proper':

\begin{tabular}{|lc||c|c:c:c|c:c|c|}
\hline$(65)$ & $\begin{array}{l}\text { I: /yi-ktib-u/ } \\
\text { B: } \text { none }\end{array}$ & $\begin{array}{c}\text { NON- } \\
\text { FINALITY }\end{array}$ & $\begin{array}{c}\text { No } \\
{[\mathrm{i}]}\end{array}$ & $\begin{array}{c}\text { PARSE } \\
-2\end{array}$ & $\begin{array}{c}\text { HEAD- } \\
\text { DEP(O/I) }\end{array}$ & $\begin{array}{c}\text { MAX } \\
(\mathrm{B} / \mathrm{O})\end{array}$ & WSP & $\begin{array}{c}\text { PARSE } \\
-\sigma\end{array}$ \\
\hline \hline a. & [(yí.kit).bu] & & $*$ & & & & $*$ & $*$ \\
\hline b. & [yi.(kít).bu] & & $*$ & & $* !$ & & & $* *$ \\
\hline c. & [(yík).ti.bu] & & $*$ & $* !$ & & & & $* *$ \\
\hline d. & [yik.(tí.bu)] & $* !$ & $*$ & & & & $*$ & $*$ \\
\hline
\end{tabular}

Notice that a derivational theory is faced with an uncomfortable uncertainty: is this a combined case of i-Syncope and i-Epenthesis, or is it a single metathesis rule? Kenstowicz \& Kisseberth (1979:230) select the second descriptive option: 'The Palestinian dialect also has a rule whereby a stem ending in the sequence CCVC is metathesised to CVCC when a vowel-initial suffix is added." Additional examples of 'metathesis' are given in (66):

$$
\begin{array}{llll}
\text { a. } & \text { /simsim-e/ } & \text { [sí.mis.me] } & \text { 'a sesame seed' } \\
\text { b. } & \text { /b-tu-drus-i/ } & \text { [btú.dur.si] } & \text { 'you fem. study' } \\
\text { c. } & \text { /zu?rut-a/ } & \text { [zú.?ur.ta] } & \text { 'a bee' }
\end{array}
$$

We now see the pressure behind 'metathesis': avoiding violation of two metrical constraints, NONFINALITY and PARSE-2. Actually the forces that lead to 'metathesis' are just the same as those leading to other vowel-zero alternations that are named 'syncope' and 'epenthesis' in a derivational theory. In OT, the need for such a terminological distinction simply disappears. The choice of epenthetic vowel in (66), [i] or [u], depends on the rounding of the vowel that precedes (Abu-Salim 1980). This is due to a harmony constraint that I will not state here.

The final ranking appears in (67):

\section{*Clash, Foot-Form, *Cluster, Head-Max(B/O) » NonFinality » No [i], Parse-2, $\operatorname{HEAD}-\mathrm{DEP}(\mathrm{O} / \mathrm{I}) \gg \operatorname{MAX}(\mathrm{B} / \mathrm{O}), \mathrm{WSP} \gg \mathrm{PARSE}-\sigma$}

This concludes the analysis of metrical opacity in Palestinian Arabic. I have argued that metrical opacity, a phenomenon that appears to form strong evidence for a derivational theory of phonology, can actually be re-interpreted as an 'identity' phenomenon, analysed in a constraintbased theory. I proposed a number of correspondence constraints that spell out requirements of identity holding between an output form on the one hand, and its base and its input on the other hand. We saw that evaluation of output forms must be parallel, in the sense that simultaneous reference is made to the base and the input. These correspondence constraints turned out to interact with constraints of syllable well-formedness, and metrical constraints that govern the shape and position of feet.

Section 3 will extend the analysis to a process of a-syncope in another Arabic dialect, that of Tripoli. This analysis will confirm two general points. First, we will find additional motivation for the notion of 'base' as I have defined it in Section 1, as a free form that is compositionally related to the output. Second, it will provide evidence for the metrical analysis and its interaction with correspondence constraints. Cases are predicted of epenthetic vowels that are stressed under duress - because of foot form constraints which dominate 'epenthetic unstressability' constraints. 


\section{Metrical opacity, syncope and epenthesis in Tripoli Arabic}

The stress-related phonology of the Tripoli dialect of Arabic has been documented in much detail by Kenstowicz \& Abdul-Karim (1980), and the following discussion will incorporate many of their insights. I will change, however, from a rule-based perspective into one based on paradigm relationships. The resulting OT analysis will improve in a number of ways over Kenstowicz \& Abdul-Karim's original analysis. Most notably, it will not use morphological structure diacritically to mark off cyclic domains. Instead the notion of 'base', as proposed earlier in $\S 1$, makes correct predictions about which morphologically related forms are in a correspondence relationship.

Three 'rules' of Tripoli Arabic will play an important role in the discussion. Below these are formulated according to Kenstowicz \& Abdul-Karim (1980):

$$
\begin{array}{llrlll}
\text { a. } & \text { a-Syncope } & \text { a [-stress }] & \rightarrow \varnothing & / & \mathrm{C}+\mathrm{V} \text { 'non-cyclic suffix' } \\
\text { b. } & \text { i-Syncope } & \mathrm{i}[\text {-stress }] \rightarrow \varnothing & \rightarrow & -\mathrm{CV} \\
\text { c. } & \text { i-Epenthesis } & \varnothing \rightarrow \mathrm{i} & / \mathrm{C}-\mathrm{C}\{\mathrm{C}, \#\}
\end{array}
$$

Two of these rules we have already seen active in Palestinian Arabic. The difference between Palestinian and the Tripoli dialect is that the latter has rule of $a$-Syncope which applies in a wide variety of contexts, whereas Palestinian restricts it to a small number of morphological contexts. This dialectal difference can be attributed to a small difference in the ranking of the constraint triggering a-Syncope. In the following sections I will discuss the highly interesting interactions between the three 'processes', and their interactions with (input) faithfulness and (base) identity.

\subsection{Underapplication of a-Syncope}

A rule of a-Syncope deletes /a/ in open unstressed nonfinal syllables (cf. 69a.ii, iii, 70a.ii, iii). Kenstowicz \& Abdul-Karim (1980:59) observe that application of this rule is blocked before a 'cyclic' suffix, that is, in accusative (69b) and possessive (70b) forms:

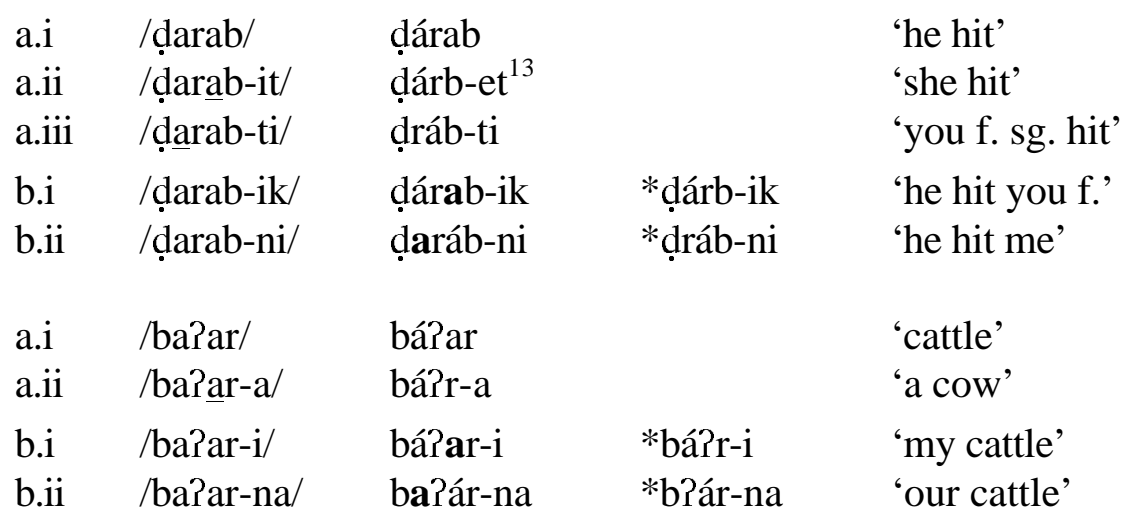

The blocking of a-Syncope in accusatives and possessives is problematic from a derivational viewpoint. Note that if a-Syncope is a cyclic rule, then it should apply within the outer cycle, e.g. [[ba?ar]-i], producing *[bá?ri]. No appeal can be made to strict cyclicity, since the rule's context arises by morpheme concatenation, stress, and resyllabification.

\footnotetext{
${ }^{13}$ The ending [-et] is an allomorph of the 3sg.fem. suffix that appears word-finally. Interestingly, a-Syncope is blocked in the 3.pl. form, which is [ụárab-u] rather than *[ụárb-u]. This might point to the 3.sg. form [ụárab] as the base of the 3.pl., to which it is compositionally related by morpheme composition, as well as by person en gender features, although not by number features.
} 
In setting up an OT analysis, the first question is: what triggers a-Syncope, a process that does not occur in Palestinian Arabic? We readily identify the 'trigger' of deletion of /a/ as a constraint that is analogous to No [i]:

\section{(71) No [a]}

[a] is not allowed in open syllables.

For obvious reasons, this constraint must dominate 'faithfulness to the input' in the Tripoli dialect, while in Palestinian (which does not have a-Syncope) the ranking must be reverse:

$$
\begin{array}{lll}
\text { a. } & \text { Tripoli: } & \text { No [i], No [a] } \gg \operatorname{MAX}(\mathrm{I} / \mathrm{O}) \\
\text { b. } & \text { Palestinian: } & \text { No [i] } \gg \operatorname{MAX}(\mathrm{I} / \mathrm{O}) » \operatorname{No}[\mathrm{a}]
\end{array}
$$

Now we may ask why a-Syncope underapplies to accusatives and possessives in the Tripoli dialect. The generalisation is that these forms are the ones that have bases. Criteria for base-hood point to (69a.i) [ụarab] as the base of the accusatives (69b.i, ii) [ḍarab-ik] and [ḍarábni], since this is a free form to which they are compositionally related. In contrast, the forms (69a.ii, iii) [ḍárb-et] and [ạráb-ti] have no base, because their verbal stem, /ḍarab/ 'to hit', does not occur uninflected.

Similar reasoning applies to the possessives [báiar-i] and [ba?ár-na] in (70b), both of which are compositionally related to a free form (71a.i) [bá?ar] 'cattle'. In contrast, no base can be identified for the singular form [bá?r-a] 'a cow', because it cannot be compositionally related (due to a conflict in number inflection with that of the plural [bá?ar] 'cattle').

Given the pairing of output forms with bases, we directly find an explanation for the 'underapplication' of a-Syncope to the first vowels in forms (69b.ii) [ḍaráb-ni] and (70b.ii) [ba?ár-na]. These vowels have stressed correspondents in the base. Hence, deleting them would violate $\operatorname{HEADMAX}(\mathrm{B} / \mathrm{O})$, which must therefore be undominated, as in Palestinian.

Interestingly, we also have an explanation for the 'underapplication' of a-Syncope to the second vowel in the accusative form (69b.i) [ḍárab-ik] and the possessive form (70b.i) [bá?ar-i]. In contrast to the initial vowels, these vowels lack stressed correspondents in their bases. We observe that /a/ is protected from deletion whenever it has a correspondent in the base (as in 73a), but that it deletes where no base occurs (as in 73b):
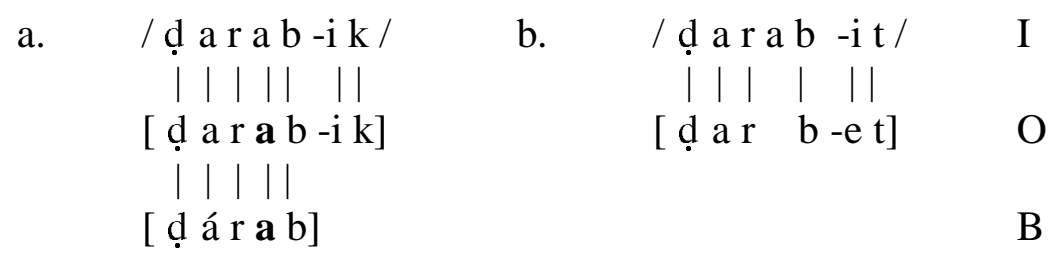

This points to a base-identity constraint requiring that base segments have correspondents in the output. This, of course, is $\mathrm{MAX}(\mathrm{B} / \mathrm{O})$, repeated below from (29):

$\operatorname{MAX}(\mathbf{B} / \mathbf{O})$

Every segment in the base has a correspondent in the output. 
$\operatorname{MAX}(\mathrm{B} / \mathrm{O})$ dominates No [a], as motivated by the 'underapplication' effects that we saw in the examples above $^{14}$. And as I have argued above, No [a] itself dominates MAX(I/O) since we find normal application of a-Syncope at the expense of (input) faithfulness in forms such as [dár.bet] 'she hit'. In section 2.1 I argued for Palestinian Arabic that $\mathrm{MAX}(\mathrm{B} / \mathrm{O})$ is ranked below No [i], while $\operatorname{HEADMAX}(\mathrm{B} / \mathrm{O})$ is ranked above it. (This ranking actually reoccurs in Tripoli, and I will give evidence for it below.) This subset of constraints is ranked as in (75):

$$
\operatorname{HEADMAX}(\mathrm{B} / \mathrm{O}) \gg \mathrm{No}[\mathrm{i}] \gg \operatorname{MAx}(\mathrm{B} / \mathrm{O}) \gg \mathrm{No}[\mathrm{a}] \gg \operatorname{MAX}(\mathrm{I} / \mathrm{O})
$$

This partial ranking is consistent with the complete ranking of Palestinian except for the subranking of No [a] with respect to $\operatorname{MAX}(\mathrm{I} / \mathrm{O})$. If we tentatively assume the remaining rankings of Palestinian for the Tripoli dialect, we arrive at:

$$
\begin{aligned}
& \text { *Clash, Foot-Form, *Cluster, Head-Max(B/O) » NonFinality » No [i], Parse-2, } \\
& \operatorname{HEAD}-\mathrm{DEP}(\mathrm{O} / \mathrm{I}) \gg \mathbf{M A X}(\mathbf{B} / \mathbf{O}), \text { WSP } » \mathbf{N o}[\mathbf{a}], \mathrm{PARSE}-\sigma \gg \mathbf{M A X}(\mathbf{I} / \mathbf{O})
\end{aligned}
$$

\begin{tabular}{|c|c|c|c|c|c|c|c|c|c|c|}
\hline$(77)$ & $\begin{array}{l}\text { I: /ḍarab-ik/ } \\
\text { B: [đ̣á.rab] }\end{array}$ & $\begin{array}{l}\text { HEAD- } \\
\text { MAX } \\
(\mathrm{B} / \mathrm{O})\end{array}$ & $\begin{array}{c}\text { NON- } \\
\text { FINAL- } \\
\text { ITY }\end{array}$ & $\begin{array}{c}\text { No } \\
{[i]}\end{array}$ & $\begin{array}{c}\text { PARSE } \\
-2\end{array}$ & $\begin{array}{c}\text { HEAD- } \\
\text { DEP } \\
(\mathrm{O} / \mathrm{I})\end{array}$ & $\begin{array}{l}\text { MAX } \\
(\mathrm{B} / \mathrm{O})\end{array}$ & WSP & $\begin{array}{l}\text { No } \\
{[a]}\end{array}$ & $\begin{array}{l}\text { MAX } \\
\text { (I/O) }\end{array}$ \\
\hline a. & [(ḍár).bik] & & & & & & *! & & & * \\
\hline b. & [(dá.ra).bik] & & & & & & & & & \\
\hline c. & [(ḍrá.bik)] & $* !$ & $*$ & & & & * & $*$ & $*$ & * \\
\hline
\end{tabular}

The tableaux in (77) and (78) illustrate the analysis. Constraints appearing in boldface in (76) re-

\begin{tabular}{|c|c|c|c|c|c|c|c|c|c|c|}
\hline$(78)$ & $\begin{array}{l}\text { I: /darab-et/ } \\
\text { B: none }\end{array}$ & $\begin{array}{c}\text { HEAD- } \\
\text { MAX } \\
\text { (B/O) } \\
\end{array}$ & $\begin{array}{c}\text { NON- } \\
\text { FINAL- } \\
\text { ITY } \\
\end{array}$ & $\begin{array}{c}\text { No } \\
{[i]}\end{array}$ & $\begin{array}{c}\text { PARSE } \\
-2\end{array}$ & $\begin{array}{c}\text { HEAD- } \\
\text { DEP } \\
(\mathrm{O} / \mathrm{I}) \\
\end{array}$ & $\begin{array}{l}\text { MAX } \\
(\mathrm{B} / \mathrm{O})\end{array}$ & WSP & $\begin{array}{l}\text { No } \\
{[a]}\end{array}$ & $\begin{array}{l}\text { MAX } \\
\text { (I/O) }\end{array}$ \\
\hline a. & ["(ḍár).bet] & & & & & & & * & & * \\
\hline b. & [(ḍá.ra).bet] & & & & & & & $*$ & $* ! *$ & \\
\hline c. & [(ḍrá.bet)] & $* !$ & $*$ & & & & $*$ & * & * & * \\
\hline
\end{tabular}
appear as such below:

As Palestinian Arabic, the Tripoli dialect has epenthesis, and opaque stress as a result of it. Consider the following tableau of /madrs-e/ [má.dir.se] 'school':

\footnotetext{
${ }^{14}$ Interestingly, the relative ranking of $\operatorname{MAX}(\mathrm{B} / \mathrm{O})$ and No $[\mathrm{a}]$ is a source of dialectal variation. As Kenstowicz \& Abdul-Karim (1980:59) report, the Kfar-Şghāb dialect (another Levantine dialect, Fleisch 1963) has extended aSyncope to apply 'before cyclic suffixes', that is, in accusative and possessive forms. This dialect has forms such as [ḍ́rb-ak] 'he hit you m.' and [sámak] 'fish, pl.', [sámk-u] 'his fish, pl.'. The application of a-Syncope in these forms follows from a demotion of $\operatorname{MAX}(\mathrm{B} / \mathrm{O})$ below No [a].
} 


\begin{tabular}{|c|c|c|c|c|c|c|c|c|c|c|}
\hline (79) & $\begin{array}{l}\mathrm{I}: \text { /madrs-e/ } \\
\mathrm{B}: \text { none }\end{array}$ & $\begin{array}{c}\text { HEAD- } \\
\text { MAX } \\
(\mathrm{B} / \mathrm{O})\end{array}$ & $\begin{array}{c}\text { NON- } \\
\text { FINAL- } \\
\text { ITY }\end{array}$ & $\begin{array}{l}\mathrm{No} \\
{[\mathrm{i}]}\end{array}$ & $\begin{array}{c}\text { PARSE- } \\
2\end{array}$ & $\begin{array}{c}\text { HEAD- } \\
\text { DEP } \\
(\mathrm{O} / \mathrm{I})\end{array}$ & $\begin{array}{l}\text { MAX } \\
(\mathrm{B} / \mathrm{O})\end{array}$ & WSP & $\begin{array}{l}\mathrm{No} \\
{[\mathrm{a}]}\end{array}$ & $\begin{array}{l}\text { MAX } \\
(\mathrm{I} / \mathrm{O})\end{array}$ \\
\hline a. & [(má.dir).se] & & & & & & & $*$ & $*$ & \\
\hline b. & [ma.(dír).se] & & & & & $* !$ & & & $*$ & \\
\hline c. & [(mád).ri.se] & & & $* !$ & $*$ & & & & & \\
\hline d. & [mad.(rí.se)] & & $* !$ & $*$ & & & & * & & \\
\hline
\end{tabular}

Tripoli Arabic also shares with Palestinian a process of i-Syncope, patterning as discussed in section 2. Again, we find the 'promiscuous' interaction between i-Syncope and i-Epenthesis that occurs in Palestinian examples such as /yi-ktib-u/, [yí.kit.bu]. See (80):
a. /tifl-e/
tíf.le
'child, f.'
b. /tifl-it-i/
tí.fil.ti
c. /tifl-it-na/
tif.lít.na
*tif.li.ti
'my child, f.'
'our child, f.

This supports the assumption, made immediately above, that the full constraint ranking of Palestinian, reached at the end of section 2, holds for Tripoli as well. (As argued earlier, the single difference is the ranking of No [a], see again 72).

\begin{tabular}{|c|c|c|c|c|c|c|c|c|c|c|}
\hline (81) & $\begin{array}{l}\text { I: /tifl-it-i/ } \\
\text { B: [țíf.le] }\end{array}$ & $\begin{array}{l}\text { HEAD- } \\
\text { MAX } \\
(\mathrm{B} / \mathrm{O})\end{array}$ & $\begin{array}{l}\text { NON- } \\
\text { FINAL- } \\
\text { ITY }\end{array}$ & $\begin{array}{c}\text { No } \\
{[\mathrm{i}]}\end{array}$ & $\begin{array}{c}\text { PARSE- } \\
2\end{array}$ & $\begin{array}{l}\text { HEAD- } \\
\text { DEP } \\
(\mathrm{O} / \mathrm{I})\end{array}$ & $\begin{array}{l}\text { MAX } \\
(\mathrm{B} / \mathrm{O})\end{array}$ & WSP & $\begin{array}{l}\mathrm{No} \\
{[\mathrm{a}]}\end{array}$ & $\begin{array}{l}\text { MAX } \\
(\mathrm{I} / \mathrm{O})\end{array}$ \\
\hline a. & [(tí.fil).ti] & & & $* *$ & & & * & * & & * \\
\hline b. & [ti.(fíl).ti] & & & $* *$ & & $* !$ & $*$ & & & $*$ \\
\hline c. & [(tíf).li.ti] & & & $* *$ & $* !$ & & & & & \\
\hline d. & [tif.(lí.ti)] & & $* !$ & $* *$ & & & & $*$ & & \\
\hline e. & [(tfíl).ti] & $* !$ & & * & & * & $* *$ & & & $*$ \\
\hline
\end{tabular}

\section{3 a-Syncope and its interactions with i-Syncope and i-Epenthesis}

The most interesting aspect of Tripoli is its triple interaction of a-Syncope, i-Syncope, and iEpenthesis. This is exemplified in (82) by 3sg. fem. accusative forms and possessives. The relevant forms in which all three processes apply are (82a.ii. b.ii). Syncopated vowels have been underlined in input forms while epenthetic vowels appear in boldface in the outputs ${ }^{15}$ :

\begin{tabular}{|c|c|c|c|c|c|}
\hline & Input & Output & Retain /a/ & Retain /i/ & Gloss \\
\hline $\begin{array}{l}\text { a.i } \\
\text { a.ii } \\
\text { a.iii }\end{array}$ & $\begin{array}{l}\text { /ḍarab-it/ } \\
\text { /ḍarab-it-u/ } \\
\text { /ḍarab-it-na/ }\end{array}$ & $\begin{array}{l}\text { ḍár.bet } \\
\text { ḍa.rib.tu } \\
\text { ḍar.bít.na }\end{array}$ & *ạa.ráb.tu & *ạár.bi.tu & $\begin{array}{l}\text { 'she hit' } \\
\text { 'she hit him' } \\
\text { 'she hit us' }\end{array}$ \\
\hline $\begin{array}{l}\text { b.i } \\
\text { b.ii } \\
\text { b.iii }\end{array}$ & $\begin{array}{l}\text { /baịar-a/ } \\
\text { /baịar-it-i/ } \\
\text { /baîar-it-na/ }\end{array}$ & $\begin{array}{l}\text { bá?.ra } \\
\text { bá.?ir.ti } \\
\text { ba?.rít.na }\end{array}$ & *ba.Pár.ti & *bár.ri.ti & $\begin{array}{l}\text { 'cow' } \\
\text { 'my cow' } \\
\text { 'our cow' }\end{array}$ \\
\hline
\end{tabular}

15 The question of what distinguishes opaque stress in [ḍarib-t-u] and non-opaque stress in [baa.rík.tu] and [?al.lím.tu] will be addressed in Section 4 below. 
Apparently it would have been more 'economic' to syncopate only one vowel, rather than to syncopate both /a/ and /i/, and substitute one by epenthesis. What causes this exchange of /a/ for [i]? In order to find out we must look at competitors that retain input /a/, as well as those that retain input /i/.

As should be clear by now, starred candidates that retain input /i/ fatally violate No [i] or PARSE-2. These constraints outrank those that are violated in actual outputs, WSP in particular. But the nonoccurrence of the candidates that retain input /a/ is more surprising. Unlike the forms that retain /i/, these do not violate No [i] nor PARSE-2. They have skeletal forms that are identical to those of the actual output forms, the single difference being that they retain the input vowel /a/, rather than deleting it and replacing it by an epenthetic [i]. The question is: why are these 'faithful' forms rejected at the expense of 'unfaithful' forms? Preserving the input vowel must be dispreferred for some reason. What can it be?

Observe that epenthetic [i] in [ḍa.rib.tu] and [bá.Pir.ti] has no correspondent in the bases of these forms, [ḍár.bet] and [bá?.ra]. If an output vowel lacks a base correspondent, then it is 'epenthetic' from the viewpoint of any constraint evaluating $B / O$-correspondence, regardless of whether it possesses an Input correspondent. Therefore the alternative forms that retain input /a/, [ḍa.rab.tu] and [bá.?ar.ti], would also be treated as 'epenthetic'. We already know from the previous discussion that the epenthetic vowel is [i], a result of the undominated ranking of IDENT[a]. Conseqently an output [i] lacking a correspondent in the input is preferred over other an output [a] lacking a correspondent in the input. If we only generalise correspondence relationships that are evaluated by these constraints from Output-Input to Output-Base, then we are able to explain the choice of (83a) over (83b):
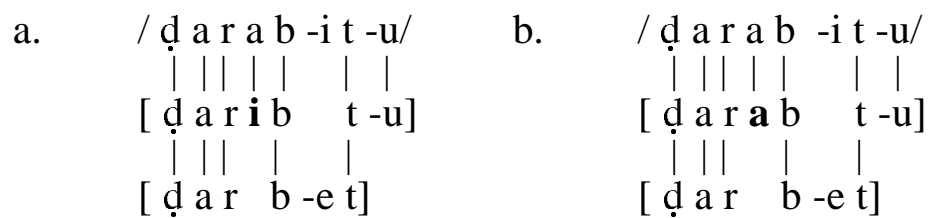
Input
Output
Base

Form (83b) fatally violates IDENT-[a], the constraint requiring that output [a] must have a base correspondent. In contrast, form (83b) only violates the lower-ranked IDENT-[i]. This completes the answer to the original question why 'less faithful' outputs are preferred over 'faithful' outputs.

The single remaining question is why [ḍa.rib.tu] and [bá.Pir.ti] have opaque stress on their initial syllables, even though their second syllables would be qualified bearers of stress from the viewpoint of HEAD-DEP(O/I). Because [i] in (83a) has a correspondent in the input, no violation of $\operatorname{HEAD}-\operatorname{DEP}(\mathrm{O} / \mathrm{I})$ would arise by stressing it, as in [ạa.ríb.tu]. However, as we observed immediately above, this output [i] has no correspondent in the base, and therefore it is treated as epenthetic by any constraint evaluating B/O-correspondence.

The answer therefore must be that opaque stress is due to non-correspondence of the output prosodic head with a vowel in the base, as a comparison of (83a, b) shows:

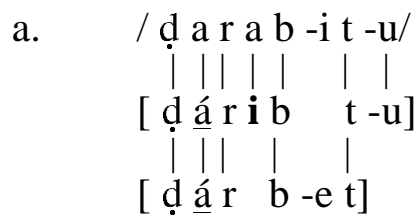
b.

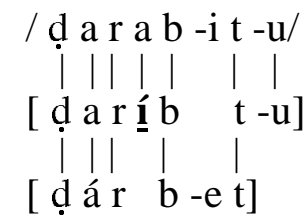

Input

Output

Base 
That is, a stressed output vowel must have a base correspondent. This is stated in:

HEAD-DEP(O/B)

Every vowel in the output prosodic head has a correspondent in the base.

If we rank this constraint in the same position as $\operatorname{HEAD-DEP}(\mathrm{O} / \mathrm{I})$, we arrive at an analysis of opaque stress in [ḍaribtu] that is illustrated in tableau (85). In the column HEAD-DEP(O/IB), I will mark violations by indicating whether a stressed output vowel lacks a correspondent in the base (by ' $\mathrm{B}$ '), or in the input (by ' $\mathrm{I}$ ').

\begin{tabular}{|c|c|c|c|c|c|c|c|c|c|}
\hline $\begin{array}{l}\text { (85) I: /ḍarab-it-u/ } \\
\text { B: [ḍar.bet] }\end{array}$ & $\begin{array}{c}\text { IDENT } \\
\text { [a] } \\
(\mathrm{IB} / \mathrm{O}) \\
\end{array}$ & $\begin{array}{l}\text { HEAD- } \\
\text { MAX } \\
(\mathrm{B} / \mathrm{O}) \\
\end{array}$ & $\begin{array}{c}\text { NON- } \\
\text { FINAL- } \\
\text { ITY } \\
\end{array}$ & $\begin{array}{l}\mathrm{No} \\
{[\mathrm{i}]}\end{array}$ & $\begin{array}{l}\text { PARSE- } \\
2\end{array}$ & $\begin{array}{l}\text { HEAD- } \\
\text { DEP } \\
(\mathrm{O} / \mathrm{IB}) \\
\end{array}$ & $\begin{array}{l}\text { MAX } \\
(\mathrm{B} / \mathrm{O})\end{array}$ & WSP & $\begin{array}{l}\mathrm{NO} \\
{[\mathrm{a}]}\end{array}$ \\
\hline a. [(ḍá.rib).tu] & & & & & & & * & $*$ & $*$ \\
\hline [ḍa.(ríb).tu] & & & & & & B! & $*$ & & $*$ \\
\hline [(ḍár).bi.tu] & & & & $* !$ & $*$ & & & & \\
\hline [ḍar.(bí.tu)] & & & $* !$ & $*$ & & & & $*$ & \\
\hline [ḍa.(ráb).tu] & $* !$ & & & & & $\mathrm{B}$ & $*$ & & $*$ \\
\hline [ḍa.(rá.bi).tu] & $* !$ & & & $*$ & & $\mathrm{~B}$ & & & $*$ \\
\hline
\end{tabular}

For comparison and to wind up this section, I give the tableau for [ḍar.bít.na] in (86):

\begin{tabular}{|c|c|c|c|c|c|c|c|c|c|}
\hline $\begin{array}{l}\text { (86) I: /ḍarab-it-na/ } \\
\text { B: [ḍár.bet] }\end{array}$ & $\begin{array}{c}\text { IDENT } \\
\text { [a] } \\
(\mathrm{IB} / \mathrm{O}) \\
\end{array}$ & $\begin{array}{l}\text { HEAD- } \\
\text { MAX } \\
(\mathrm{B} / \mathrm{O})\end{array}$ & $\begin{array}{c}\text { NON- } \\
\text { FINAL- } \\
\text { ITY } \\
\end{array}$ & $\begin{array}{l}\mathrm{No} \\
{[\mathrm{i}]}\end{array}$ & $\begin{array}{l}\text { PARSE- } \\
2\end{array}$ & $\begin{array}{l}\text { HEAD- } \\
\text { DEP } \\
(\mathrm{O} / \mathrm{IB}) \\
\end{array}$ & $\begin{array}{l}\text { MAX } \\
(\mathrm{B} / \mathrm{O})\end{array}$ & WSP & $\begin{array}{l}\mathrm{No} \\
{[\mathrm{a}]}\end{array}$ \\
\hline a. [ḍar.(bít).na] & & & & & & & & & \\
\hline b. [(ḍár).bit.na] & & & & & $* !$ & & & & \\
\hline c. [(ḍà.ra).(bít).na] & $* !$ & & & & & & & & \\
\hline
\end{tabular}

The final section of this article will demonstrate that this analysis correctly predicts a property that caused great troubles to earlier derivational analyses: epenthetic vowels may be stressed 'under duress', due to foot well-formedness.

\section{Stressed epenthetic vowels in Tripoli Arabic}

Consider the following partial verbal paradigm of the $\mathrm{CvCvC}$ stem /darab/ 'to hit', to that of a $\mathrm{CvvCvC}$ stem /baarak/ 'to bless' and a $\mathrm{CvCCvC}$ stem /?allam/ 'to teach':
a.i /ḍarab-it/
ḍár.bet
'she hit'
a.ii /ḍarab-it-u/
dá.rib.tu
a.iii /ḍarab-it-na/
ḍar.bít.na
'she hit him'
b.i /baarak-it/
báar.ket
b.ii /baarak-it-u/
baa.rík.tu
'she hit us'
b.iii /baarak-it-na/
baar.kít.na
'she blessed'
c.i /Rallam-it/
Páll.met
c.ii /Rallam-it-u/
Pal.lím.tu
c.iii /Pallam-it-na/
Pall.mít.na
'she blessed him'
'she blessed us'
'she taught'
'she taught him'
'she taught us' 
When we compare the accusative forms (87a.ii) to (87b.ii, c.ii) we observe that the position of the epenthetic vowels is identical, but that there is a difference in the position of stress. In the former this vowel is unstressed, whereas in the latter the epenthetic vowels are stressed. Kenstowicz \& Abdul-Karim (1980) observe that where an epenthetic vowel is stressed, the syllable that precedes it is heavy.

A similar relationship holds between the possessives based on $\mathrm{CvCvC}$ nouns (/baiar/ 'cow', 88a) and those based on shapes $\mathrm{CvCCvC}$ (/maktab/ 'library', 88a).

$\begin{array}{llll}\text { a.i } & \text { /baịar-a/ } & \text { bár.ra } & \text { 'cow' } \\ \text { a.ii } & \text { /baịar-it-i/ } & \text { bá.?ir.ti } & \text { 'my cow' } \\ \text { a.iii } & \text { /baịar-it-na/ } & \text { ba?.rít.na } & \text { 'our cow' } \\ \text { b.i } & \text { /maktạb-e/ } & \text { má.kit.be } & \text { 'library' } \\ \text { b.ii } & \text { /maktab-it-i/ } & \text { mak.tíb.ti } & \text { 'my library' } \\ \text { b.iii } & \text { /maktab-it-na/ } & \text { ma.kit.bít.na } & \text { 'our library' }\end{array}$

Finally this relationship holds between possessives of CvCC nouns (/tifl/ 'child', 89a) and those of CvCCC nouns (/madrs/ 'school', 88b), and CvvCC nouns (/taawl/ 'table', 88c):

$\begin{array}{llll}\text { a.i } & \text { /țifl-e/ } & \text { tíf.le } & \text { 'child, f.' } \\ \text { a.ii } & \text { /țifl-it-i/ } & \text { tí.fil.ti } & \text { 'my child, f.' } \\ \text { a.iii } & \text { /țifl-it-na/ } & \text { tif.lít.na } & \text { 'our child, f. } \\ \text { b.i } & \text { /madrs-e/ } & \text { má.dir.se } & \text { 'school' } \\ \text { b.ii } & \text { /madrs-it-i/ } & \text { mad.rís.ti } & \text { 'my school' } \\ \text { b.iii } & \text { /madrs-it-na/ } & \text { ma.dir.sít.na } & \text { 'our school' } \\ \text { c.i } & \text { /taawl-e/ } & \text { táaw.le } & \text { 'table' } \\ \text { c.ii } & / \text { taawl-it-i/ } & \text { taa.wíl.ti } & \text { 'my table' } \\ \text { c.iii } & \text { /taawl-it-na/ } & \text { taaw.lít.na } & \text { 'our table' }\end{array}$

The question is, why do we find opaque stress in [ḍa.rib.tu], but transparent stress in [baa.rík.tu]? If epenthetic vowels consistently reject stress, then we would expect stress to fall on the initial syllable regardless of its weight:

$$
\begin{array}{llll}
\text { a. } & *[(\text { báa).rik.tu }] & > & \text { [baa.(rík).tu }] \\
\text { b. } & *[\text { (mák).tib.ti] } & > & {[\text { mak.(tíb).ti }]}
\end{array}
$$

The generalisation that a heavy syllable must precede in order for an epenthetic vowel to be stressed points to an interaction between metrical constraints and the constraints that require that epenthetic vowels must be unstressed, that is, HEAD-DEP (O/IB).

Only a small modification of the analysis is required to produce this interaction. Both of the metrical constraints FOOT-FORM and PARSE- 2 must come to dominate HEAD-DEP (O/IB). The constraint hierarchy can now be stated in its final form in (91):

*Clash, Foot-Form, *Cluster, Head-Max(B/O) » NOnFinality » No [i], PARSE-2 » $\operatorname{HEAD}-\mathrm{DEP}(\mathrm{O} / \mathrm{I}) \gg \operatorname{MAX}(\mathrm{B} / \mathrm{O}), \mathrm{WSP} \gg \mathrm{No}[\mathrm{a}], \mathrm{PARSE}-\sigma$ » $\mathrm{MAX}(\mathrm{I} / \mathrm{O})$ 
To illustrate this analysis I present the following tableaux:

\begin{tabular}{|c|c|c|c|c|c|c|c|c|c|}
\hline $\begin{array}{c}\text { (92) I: /baarak-it-u/ } \\
\text { B: [báar.ket] }\end{array}$ & $\begin{array}{c}\text { IDENT } \\
\text { [a] } \\
(\mathrm{IB} / \mathrm{O}) \\
\end{array}$ & $\begin{array}{l}\text { FOOT- } \\
\text { FORM }\end{array}$ & $\begin{array}{c}\text { NON- } \\
\text { FINAL- } \\
\text { ITY } \\
\end{array}$ & $\begin{array}{l}\mathrm{No} \\
{[\mathrm{i}]}\end{array}$ & $\begin{array}{l}\text { PARSE- } \\
2\end{array}$ & $\begin{array}{c}\text { HEAD- } \\
\text { DEP } \\
(\mathrm{O} / \mathrm{IB}) \\
\end{array}$ & $\begin{array}{l}\text { MAX } \\
(\mathrm{B} / \mathrm{O})\end{array}$ & WSP & $\begin{array}{l}\mathrm{No} \\
{[\mathrm{a}]}\end{array}$ \\
\hline a. $[$ baa.(rík).tu] & & & & & & $*$ & $*$ & $*$ & \\
\hline b. [(báa).rik.tu] & & & & & $* !$ & & $*$ & $*$ & \\
\hline c. [baa.(rá.ki).tu] & & & & $* !$ & & $*$ & & $*$ & $*$ \\
\hline d. [(báar).ki.tu] & & & & $* !$ & $*$ & & & & \\
\hline e. $\quad$ [baar.(kí.tu)] & & & $* !$ & $*$ & & & & $*$ & \\
\hline f. [(báa.rik).tu] & & $* !$ & & & & & $*$ & $*$ & \\
\hline g. [baa.(rák).tu] & $* !$ & & & & & $*$ & $*$ & $*$ & \\
\hline
\end{tabular}

\begin{tabular}{|c|c|c|c|c|c|c|c|c|c|}
\hline $\begin{array}{l}\text { (92) I: /madrs-it-i/ } \\
\text { B: [má.dir.se] }\end{array}$ & $\begin{array}{c}\text { IDENT } \\
\text { [a] } \\
(\mathrm{IB} / \mathrm{O}) \\
\end{array}$ & $\begin{array}{l}\text { FOOT- } \\
\text { FORM }\end{array}$ & $\begin{array}{c}\text { NON- } \\
\text { FINAL- } \\
\text { ITY } \\
\end{array}$ & $\begin{array}{l}\mathrm{NO} \\
{[\mathrm{i}]}\end{array}$ & $\begin{array}{c}\text { PARSE- } \\
2\end{array}$ & $\begin{array}{c}\text { HEAD- } \\
\text { DEP } \\
(\mathrm{O} / \mathrm{IB}) \\
\end{array}$ & $\begin{array}{l}\text { MAX } \\
(\mathrm{B} / \mathrm{O})\end{array}$ & WSP & $\begin{array}{l}\mathrm{No} \\
{[\mathrm{a}]}\end{array}$ \\
\hline a. [mad.(rís).ti] & & & & $*$ & & $*$ & *** & $*$ & \\
\hline b. [(mád).ris.ti] & & & & $*$ & $* !$ & & $* *$ & $*$ & \\
\hline c. [mad.(rí.si).ti] & & & & $* * ! *$ & & $*$ & $*$ & $*$ & \\
\hline d. [ma.(dír).si.ti] & & & & $* * !$ & $*$ & $*$ & & & $*$ \\
\hline e. [(mád.ris).ti] & & $* !$ & & $*$ & & & $* *$ & $*$ & \\
\hline
\end{tabular}

\begin{tabular}{|c|c|c|c|c|c|c|c|c|c|}
\hline $\begin{array}{l}\text { (93) I: /maktab-it-i/ } \\
\text { B: [má.kit.be] }\end{array}$ & $\begin{array}{c}\text { IDENT } \\
{[\mathrm{a}]} \\
(\mathrm{IB} / \mathrm{O}) \\
\end{array}$ & $\begin{array}{l}\text { FOOT- } \\
\text { FORM }\end{array}$ & $\begin{array}{c}\text { NON- } \\
\text { FINAL- } \\
\text { ITY } \\
\end{array}$ & $\begin{array}{l}\mathrm{No} \\
{[\mathrm{i}]}\end{array}$ & $\begin{array}{c}\text { PARSE- } \\
2\end{array}$ & $\begin{array}{c}\text { HEAD- } \\
\text { DEP } \\
(\mathrm{O} / \mathrm{IB}) \\
\end{array}$ & $\begin{array}{l}\text { MAX } \\
(\mathrm{B} / \mathrm{O})\end{array}$ & WSP & $\begin{array}{l}\mathrm{No} \\
{[\mathrm{a}]}\end{array}$ \\
\hline a. $\Leftrightarrow[m a k .(t i ́ b) . t i]$ & & & & $*$ & & $*$ & $* *$ & * & \\
\hline b. [(mák).tib.ti] & & & & * & $* !$ & & $* *$ & $*$ & \\
\hline c. [ma.(kít).bi.ti] & & & & $* * !$ & $*$ & $*$ & & & $*$ \\
\hline d. [(mák.tib).ti] & & $* !$ & & $*$ & & & $* *$ & $*$ & \\
\hline e. [mak.(táb).ti] & $* !$ & & & $*$ & & $*$ & $* *$ & $*$ & \\
\hline f. [mak.(tá.bi).ti] & $* !$ & & & $* *$ & & $*$ & $*$ & $*$ & $*$ \\
\hline
\end{tabular}

\subsection{Alternative accounts}

Kenstowicz \& Abdul-Karim (1980) base their analysis on the observation that epenthetic [i] in Tripoli is stressed iff it it lands in a position in which a vowel is stressed in the (Ramallah) Palestinian dialect:

$$
\begin{array}{lll}
\text { a. Tripoli: } & \text { [ḍa.rib.tu] } \\
\text { b. } & \text { Palestinian: } & \text { [ḍár.ba.to] }
\end{array}
$$
[baa.rík.tu]
[baa.rá.ka.to]
[?al.lím.tu]
[?al.lá.ma.to]

The idea is that the basic metrical structures of the dialects are identical, but that dialects have different syncope rules. Metrification is due to a left-to-right rightward assignment of a quantitative foot, which may be seen as a far ancestor of the moraic trochee. Constituency is preserved through cyclic stress and syncope, 'unifying' with epenthetic [i] post-cyclically. An epenthetic vowel surfaces as stressed if it 'lands' into a metrical position that was strong in the original parsing. This requires an intermediate step of 'floating feet' for Tripoli: 

a. $\quad[(\mathbf{L L})(\mathrm{LL})]$
[(ḍá.r_).(b .tu)]
b. $\quad[(\mathrm{H})(\mathbf{L L}) \mathrm{L}]$
[(baa).(r_.k ).tu]
[(?al).(1_m ).tu]

Similar analyses of related Levantine dialects are Irshied \& Kenstowicz (1984), Al-Mozainy, Bley Vroman \& McCarthy (1985), and Hayes (1995).

The central conceptual problem to this type of analysis is that the foot parsings that 'explain' the stress values of epenthetic vowels never surface in Tripoli, because of excessive syncope in long strings of light syllables. Therefore the position of epenthetic vowels within feet may be inferred only from the stress value of these vowels, producing circularity. (As Kenstowicz \& Abdul-Karim notice: "[...] suffixed 3 sg.f. perfects and feminine nouns in construct are the only places where the morphology of Levantine Arabic permits words of four light syllables to be constructed."

A second type of analysis is based on 'degenerate' syllables rather than floating feet (Broselow 1992). Epenthesis is the assignment of a syllable nucleus (i.e. minimally a mora) in a string of consonants that cannot be syllabified (Itô 1989). Consonants syllabify as moraic in degenerate syllables, but there is pressure on degenerate syllables to be bimoraic, due to a Bimoraicity Constraint (a slightly different analysis is presented by Piggott 1995):

a.

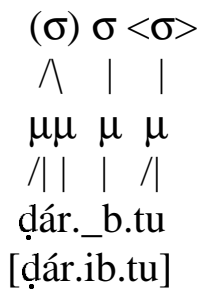

b.

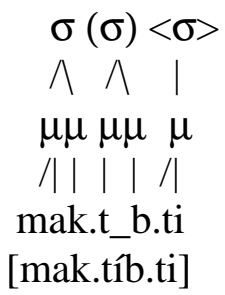

The stress contrast results from the assumption that the /r/ in (96a) syllabifies 'backward', so as to contribute to the bimoraicity of the preceding syllable. In contrast, the first /t/ in (96b) is syllabified as an onset of the degenerate syllable [t_b], since the preceding syllable [mak] is already maximal as it is. The result is a bimoraic epenthetic syllable in (96a), and a bimoraic one in (96b).

I identify three problems for this analysis. First, the bimoraic syllabification of $/ \mathrm{tb} / \mathrm{in}(96 \mathrm{~b})$ requires a moraic onset. Even as an intermediate step in a derivation, this is a highly questionable assumption. Second, this analysis fails to predict non-opaque stress in Tripoli forms in which a long vowel is involved, rather than a triconsonantal cluster. The underlying representation /baarikit-u/ might syllabify as [báar._k.tu] since CvvC syllables are allowed in word-internal positions, cf. [báar.ket]. Third, why should epenthetic vowels be inserted in pre-consonantal position, e.g. [ḍáribtu] > * duárbitu], in violation of the constraint ONSET? This cannot follow from the Bimoraicity Constraint. (In my analysis, which does not make the assumption that / $\mathrm{r}$ / syllabifies 'backward', this follows from No [i].)

\section{Conclusions}

The OT analysis of Levantine Arabic stress and vowel-zero alternations which I presented in this paper has lead to the following conclusions. Although metrical opacity apparently gives severe problems to Optimality Theory, there is in fact an OT counterpart to the derivational mechanism of the cycle: base/output-correspondence. This requires no abstract intermediate levels of representation in accounting for opaque stress as in rule-based analyses. I proposed a definition of 
'base' as a compositionally related, free form. Finally, I have argued that the evaluation of output forms is parallel in $\mathrm{B} / \mathrm{O}$ and $\mathrm{I} / \mathrm{O}$ correspondence.

\section{References}

Abu-Salim, Issam M. (1980), "Epenthesis and geminate consonants in Pelestinian Arabic", Studies in the Linguistic Sciences 10.2, 1-11.

Alderete, John (1995), Faithfulness to Prosodic Heads. Ms., University of Massachusetts, Amherst. (Paper presented at Tilburg Conference on The Derivational Residue in Phonology.)

Al-Mozainy, Hamza Q., Robert Bley-Vroman, and John McCarthy (1985), "Stress shift and metrical structure", Linguistic Inquiry 16, 135-144.

Benua, Laura (1995), "Identity effects in morphological truncation", in J. Beckman, S. Urbanczyk \& L. Walsh (eds.), University of Massachusetts Occasional papers in Linguistics 18: Papers in Optimality Theory. Amherst, MA: Graduate Linguistic Student Association.

Brame, Michael (1974), "The cycle in phonology: Stress in Palestinian, Maltese, and Spanish", Linguistic Inquiry 5, 39-60.

Broselow, Ellen (1992), "Parametric variation in Arabic dialect phonology", in E. Broselow, M. Eid, \& J. McCarthy (eds.), Perspectives on Arabic Linguistics IV. Papers from the Fourth Annual Symposium on Arabic Linguistics. Amsterdam-Philadelphia: John Benjamins.

Buckley, Eugene (1995), "Cyclicity and correspondence", abstract submitted to the Tilburg Conference on The Derivational Residue in Phonology.

Burzio, Luigi (1994), Principles of English Stress. Cambridge: Cambridge University Press.

Clements, G.N. (1990), "The role of the sonority cycle in core syllabification", in: J. Kingston \& M. Beckman (eds.), Papers in Laboratory Phonology I: Between the Grammar and Physics of Speech, 283-333. New York: Cambridge University Press.

Dresher, Elan, and Aditi Lahiri (1191), "The Germanic foot: Metrical coherence in Old English", Linguistic Inquiry 22, 251-286.

Fleisch, H. (1963), "Le parler arabe de Kfar-Sghâb", Bulletin d'Etudes Orientales, Institut Francais de Damas 18, 95-125.

Halle, Morris \& Michael Kenstowicz (1989), On cyclic and noncyclic stress, unpublished ms., MIT.

Hayes, Bruce (1995), Metrical Stress Theory: Principles and Case Studies. Chicago: The University of Chicago Press.

Hooper, Joan (1976), An Introduction to Natural Generative Phonology. New York: Academic Press.

Irshied, Omar, \& Michael Kenstowicz (1984), "Some phonological rules of Bani-Hassan Arabic: A Bedouin dialect”, Studies in the Linguistic Sciences 14.1, 109-147.

Kager, René (1993), "Alternatives to the Iambic-Trochaic Law", Natural Language and Linguistic Theory 11, 381-432.

Kager, René (1994), Ternary stress in alignment theory, ms. Utrecht University.

Kager, René (1997), "Rhythmic vowel deletion in Optimality Theory", in I. Roca (ed.), Derivations and Constraints in Phonology, 463-499. Oxford University Press.

Kager, René (forthcoming), "Stem stress and peak correspondence in Dutch", to appear in J. Dekkers, F. van der Leeuw, \& J. van de Weijer (eds.), The Pointing Finger: Conceptual Studies in Optimality Theory. Amsterdam: HIL.

Kenstowicz, Michael (1983), "Parametric variation and accent in the Arabic dialects", CLS 19, 205-213. 
Kenstowicz, Michael (1995), Base-Identity and Uniform Exponence: Alternatives to Cyclicity. Ms., Massachusetts Institute of Technology.

Kenstowicz, Michael \& Kamal Abdul-Karim (1980), "Cyclic stress in Levantine Arabic", Studies in the Linguistic Sciences 10.2, 55-76.

Kenstowicz, Michael \& Charles Kisseberth (1979), Generative Phonology: Description and Theory. New York: Academic Press.

Kiparsky, Paul (1982), "From cyclic phonology to Lexical Phonology", in H. van der Hulst and N. Smith (eds.), The Structure of Phonological Representations, Part 2. Dordrecht: Foris.

Kiparsky, Paul (1995), Livonian St $\phi d$. Handout of presentation at workshop on Diachrony and Prosodic Theory, University of Nijmegen, September 6, 1995.

Kisseberth, Charles (1970), “On the functional unity of phonological rules”, Linguistic Inquiry 1, 291-306.

McCarthy, John (1979), “On stress and syllabification”, Linguistic Inquiry 10, 443-465.

McCarthy, John (1995a), Extensions of Faithfulness: Rotuman Revisited. Ms., University of Massachusetts, Amherst.

McCarthy, John (1995b), "Remarks on phonological opacity in Optimality Theory", to appear in J. Lecarme, J. Lowenstamm \& U. Shlonsky (eds.), Proceedings of the Second Colloquium on Afro-Asiatic Linguistics (Sofia Antipolis, June 1994).

McCarthy, John, \& Alan Prince (1993), "Generalized alignment", in G.E. Booij \& J. van Marle (eds), Yearbook of Morphology 1993, 79-153. Dordrecht: Kluwer.

McCarthy, John \& Alan Prince (1995), "Faithfulness and reduplicative identity", in J. Beckman, S. Urbanczyk, \& L. Walsh (eds.), University of Massachusetts Occasional Papers in Linguistics 18: Papers in Optimality Theory, 249-384. Amherst: Graduate Linguistic Student Association.

Myers, Scott (1987), "Vowel shortening in English", Natural Language and Linguistic Theory 5.4, 485-518.

Orgun, C. Orhan (1995), Correspondence and Identity Constraints in Two-Level Optimality Theory. Ms., University of California, Berkeley.

Orgun, C. Orhan (1996), Sign-Based Morphology: A Declarative Theory of PhonologyMorphology Interleaving. Ms., University of California, San Diego.

Piggott, G.L. (1995), "Epenthesis and syllable weight", Natural language and Linguistic Theory 13.2, 283-326.

Schane, Sanford (1968), French Phonology and Morphology, Cambridge, Massachusetts: MIT Press.

Steriade, Donca (1996), "Paradigm uniformity and the phonetics-phonology boundary", paper presented at the 5th Conference in Laboratory Phonology, Evanstan-Illinois, July 1996.

Zimmer, K. (1975), "Some thoughts on likely phonologies for non-ideal speakers". In R. Grossman et al. (eds.), Papers from the Parasession on Functionalism, 556-567. Chicago: Chicago Linguistics Society. 